\title{
The Four Kingdoms of Daniel in the Early Mediaeval Apocalyptic Tradition
}

\author{
Lorenzo DiTommaso
}

\section{1 \\ Introduction*}

The four kingdom schema is a historiographic framework that divides the last phase of human history into four periods, each period ruled in turn by a dominant power or world-empire. Although it originated in classical antiquity, ${ }^{1}$ the schema received its enduring formulation in chapters 2 and 7 of the biblical book of Daniel, where it acquired an apocalyptic valence. ${ }^{2}$ There the schema is presented in the form of heavenly revelation, ${ }^{3}$ which gave it a predetermined dimension. ${ }^{4}$ Both chapters expect the fourth kingdom to be overthrown by the eschatological kingdom of God, thus terminating the sequence. ${ }^{5}$

The four kingdoms are never named but instead are identified symbolically. 6 In chapter 2, King Nebuchadnezzar dreams of a giant statue that is composed

* Research for this article has been funded by 2011-16 and 2018-23 grants from the Social Sciences and Humanities Research Council of Canada, for which I am grateful. I thank Loren Stuckenbruck and Andrew Perrin for their invitation to submit a version of my conference paper to this volume.

1 Joseph Ward Swain, "The Theory of the Four Monarchies: Opposition History under the Roman Empire," CP 25 (1940): 1-21; and Samuel K. Eddy, The King is Dead: Studies in the Near Eastern Resistance to Hellenism 334-31 BC (Lincoln: University of Nebraska Press, 1961). On the construction of time and history in the Seleucid era, see now Paul J. Kosmin, Time and Its Adversaries in the Seleucid Empire (Cambridge, MA: Harvard University Press, 2019).

2 On the apocalyptic understanding of history, see Lorenzo DiTommaso, "History and Apocalyptic Eschatology: A Reply to J.Y.Jindo," VT 56 (2006): 413-18; and Lorenzo DiTommaso, "Apocalyptic Historiography," EC 10 (2019): 435-6o.

3 Cf. also Dan 8:8.

4 The classic study of the four kingdom schema in Daniel remains Reinhard G. Kratz, Translatio imperii: Untersuchungen zu den aramäischen Danielzählungen und ihrem theologiegeschichtlichen Umfeld, wMANT 63 (Neukirchen-Vluyn: Neukirchener, 1991). Dated but still valuable is David Flusser, "The Four Empires in the Fourth Sibyl and the Book of Daniel," IOS 2 (1972): $148-75$.

5 The imminence of this event is a logical corollary of the underlying apocalyptic worldview and necessary to its social functions. In the case of the revelatory visions of MT Daniel 7-12, the imminence of the end is implicit in chapter 9 and explicit in the "countdown" dates of Dan 7:25; 8:14; 12:11; and 12:12.

6 The exception is Dan 2:37-38, where Daniel explains to Nebuchadnezzar, "You, O king ... you are the head of gold" (NRSv). In its present context in the MT book, the reference is to

(C) LORENZO DITOMMASO, 2021 | DOI:10.1163/9789004443280_012

This is an open access chapter distributed under the terms of the CC BY-NC-ND 4rolicense 
of four metals of descending value, gold, silver, bronze, and iron. In chapter 7 , Daniel is shown a vision of the four hybrid-beasts that crawl out of the sea, one after the other. The fourth beast is the most terrible of all and has iron teeth.

The ambiguity of the images was critical to the schema's enduring significance, since it allowed for later interpretations in light of new circumstances. The cardinal issue was the identity of the fourth and final world-kingdom. Its overthrow represents the turning-point in the divine plan for history that was approaching its foreordained culmination. Equating the fourth kingdom with a present-day kingdom or state enabled a group to locate itself within the sequence of this history, thus placing it on the cusp of salvation. ${ }^{7}$

The book of Daniel attained its final Masoretic form towards the end of the Maccabean Revolt of 167-164 BCE. Its simplified view of the conflict, coded by its symbolic imagery, pit traditionalist Jews against their Seleucid (Hellenistic Greek) overlords, whose monarch, Antiochus Iv Epiphanes, had desecrated the Jerusalem Temple. For the intended audience of the book, the fourth and final kingdom was the oppressive Seleucid Empire. This identification is reinforced elsewhere by allusions to the hated Antiochus, ${ }^{8}$ including a skeleton version of the schema in chapter 8 (in which all the kingdoms but the first are named $)^{9}$ and the introduction of a different schema of "seventy weeks" in chapter $9 \cdot{ }^{10}$

Antiochus perished and his kingdom was overthrown, though not as the book of Daniel had predicted. ${ }^{11}$ Over the next 150 years, the Seleucid Empire and the other Hellenistic states fell to Rome like dominoes. Even to its contemporary chroniclers, Rome's rise to supreme world power seemed to have

Nebuchadnezzar's (neo-Babylonian) kingdom, rather than to the king personally. See also "Conclusions" below.

7 On the dynamics of historical periodization, see M. D. Goulder, "The Phasing of the Future," in Texts and Contexts: Biblical Texts in Their Textual and Situational Contexts: Essays in Honor of Lars Hartman, ed. Tord Fornberg and David Hellholm (Oslo: Scandinavian University Press, 1995), 391-408; Piero Capelli, "Periodizzazioni del tempo: la soluzione apocalittica," RSB 9 (1997): 193-214; John J. Collins, Apocalypticism in the Dead Sea Scrolls (London: Routledge, 1997), 52-70; and Michael E. Stone, Ancient Judaism: New Visions and Views (Grand Rapids: Eerdmans, 2011), 59-89.

8 Cf. Dan 7:8, 24b-26; 8:9-12, 23-25; 9:26-27; and 11:21-39.

9 Dan 8:20-21a: "As for the ram that you saw with the two horns, these are the kings of Media and Persia. The male goat is the king of Greece ..." (NRSv).

10 Cana Werman, "Epochs and End-Time:The 49o-Year Scheme in Second Temple Literature," DSD 13 (2006): 229-55.

11 Dan 11:40-45 incorrectly foretells the manner of Antiochus's death. For this reason it should be regarded as a genuine prediction rather than an ex eventu prophecy. 
been foreordained. ${ }^{12}$ By the second century CE, Rome had become the "empire without end" (imperium sine fine), extending from Mesopotamia in the East to the Pillars of Hercules in the West.

For the Jews and the Christians of the era, ${ }^{13}$ the final kingdom ${ }^{14}$ was no longer the "Greece" of the intended audience of Daniel and the other early apocalypses, but world-spanning Rome. ${ }^{15}$ This identification remained consistent throughout the late-antique period in both rabbinic Judaism and patristic Christianity. In the latter, it found its classic expression in Jerome's commentary on Daniel. ${ }^{16}$

The sack of Rome in $410 \mathrm{CE}$ and the withdrawal of Imperial authority in the West mark the gradual transition to the mediaeval centuries but a sharp turning-point in the history of apocalyptic speculation. This paper examines the four kingdom schema of Daniel in the early mediaeval writings, from the

12 Polybius's Histories, written in the late 140 or 130 BCE, stresses the role of fate in Rome's rise to power.

13 The identification of the fourth empire with Rome does not predate the first century всЕ; see Doron Mendels, "The Five Empires: A Note on a Propagandistic Topos," AJP 102 (1981): $33^{0}-37$.

14 In most renditions, Rome replaces Greece as the new fourth (and final) empire, with Greece shifted back one position to the third empire. Rome is sometimes added to the schema, becoming the fifth (and final) empire. On the "fifth empire" topos generally, see Maria Ana Travassos Valdez, Historical Interpretations of the "Fifth Empire": The Dynamics of Periodization from Daniel to António Vieira, S. J., SHCT 149 (Leiden: Brill, 2010).

15 The loci classici here are the "Eagle Vision" of 4 Ezra 11-12 and Josephus, Ant. In the former, Ezra the seer is shown a vision of a great eagle, with three heads and multiple wings, which is identified as the fourth and final world-kingdom (11:39-40). The eagle, of course, is symbolic of Imperial Rome, and hence refers to the "new" final kingdom. The interpreting angel clarifies the exegetical update for the seer (and its intended audience): "This is the interpretation of this vision that you have seen: The eagle that you saw coming up from the sea is the fourth kingdom that appeared in a vision to your brother Daniel. But it was not explained to him as I now explain to you or have explained it" (12:10-12 NRsv, my italics). On Daniel in Josephus, see Steve Mason, "Josephus, Daniel, and the Flavian House," in Josephus and the History of the Greco-Roman Period: Essays in Memory of Morton Smith, ed. Fausto Parente and Joseph Sievers, SP B 41 (Leiden: Brill, 1994), 161-91.

16 Franciscus Glorie, ed., Commentariorum in Danielem libriIII, CCSA 75A (Turnhout: Brepols, 1964), q.v. 2:40 and 7:7. See Régis Courtray, "Der Danielkommentar des Hieronymus," in Die Geschichte der Daniel-Auslegung in Judentum, Christentum und Islam, ed. Katharina Bracht and David S. Du Toit, BZAW 371 (Berlin: Walter de Gruyter, 2007), 123-5o, esp. 14044; and Régis Courtray, Prophète des temps derniers: Jérôme commente Daniel, тн 119 (Paris: Beauchesne, 2009), q.v. the same passages. On 7:7, see Jay Braverman, Jerome's Commentary on Daniel: A Study of Comparative Jewish and Christian Interpretations of the Hebrew Bible, свфмs 7 (Washington, DC: Catholic Biblical Association of America, 1978), 90-94. Minority versions persisted throughout antiquity, including the view that the fourth kingdom still referred to the "Greeks." 
fifth to the twelfth centuries. ${ }^{17}$ Several reasons suggest terminating our investigation at that point in time, as we shall see.

\section{The Common Mediaeval Apocalyptic Tradition}

The history of apocalyptic speculation can be divided into six periods: early, late-antique, mediaeval, early-modern, modern, and contemporary. ${ }^{18}$ These periods do not precisely correlate to historical eras. While the end of late antiquity is often pegged to the rise of Islam in the seventh century, late-antique apocalypticism actually disappeared in the late fourth and fifth centuries. In its place arose a new, mediaeval mode of apocalyptic speculation. This new mode differed radically from the late-antique variety that preceded it, and remained dominant throughout the "mediaeval millennium," which lasted approximately from the fifth to the fifteenth centuries.

It is easy to slip into generalities when outlining an apocalyptic tradition that extends over a thousand years and encompasses so many regional ecologies. Sassanid Syria is not Merovingian Gaul, and neither is ninth-century Byzantium or fifteenth-century Florence, and the apocalyptic tradition in each setting is distinctive. Apocalyptic speculation has social functions that are geared to the specific groups to which the texts are intended, and the concerns and needs of these audiences differed.

Underpinning this diversity, however, is a similarity that expresses itself in structure, content, and social function. This similarity is so global in its scope and so pervasive across the full range of the evidence, that one can identify a

17 Brennan W. Breed, "History of Reception," in Daniel: A Commentary by Carol A. Newsom with Brennan W. Breed, oTL (Louisville: Westminster John Knox, 2014), 85-97, is the best overview of the subject. The unpublished dissertation of Janet L. R. Melnyk ("The Four Kingdoms in Daniel 2 and 7: Chapters in the History of Interpretation," [PhD diss., Emory University, 2001]) jumps from Jerome to Joachim and thus skips the early mediaeval era. The PhD dissertation by E. J. J. Kocken, published as De Theorie van der vier Wereldrijken en van de Overdracht der Wereldheerschappij tot op Innocentius III (Nijmegen: Berkhout, 1935), remains a fine source-book, as does, more generally, Bernard McGinn, Visions of the End: Apocalyptic Traditions in the Middle Ages, rev. ed. (New York: Columbia University Press, 1998).

18 On the history of apocalypticism, its periods, and the contemporary "apocalyptic shift," see Lorenzo DiTommaso, "Apocalypticism in the Contemporary World," in The Cambridge Companion to Apocalyptic Literature, ed. Colin McAllister (Cambridge: Cambridge University Press, 2020), 316-42. 
common mediaeval apocalyptic tradition. ${ }^{19}$ In brief, this tradition is described by a suite of five characteristics:

(1) Its "global" geographic scope. The mediaeval apocalyptic tradition was universal in its compass, ranging across the Byzantine and Islamic worlds in the East and all points of the mediaeval West. From Ireland to Armenia, nothing "apocalyptic" was external to this geography, just as there was no regional or religious ecology that was isolated and different from the common tradition. ${ }^{20}$

(2) Its historical-eschatological tenor. There are two types of apocalyptic speculation, "historical" and "otherworldly."21 Mediaeval apocalyptic speculation tout court is of the historical-eschatological type, and almost exclusively so, in sharp contrast to the apocalyptic writings of the lateantique period that preceded it. The preponderance is all the more striking when we recall that we are dealing with literally thousands of mediaeval Christian, Jewish, and Islamic apocalyptic texts, tracts, testaments, commentaries, oracles, prophecies, homilies, and other literary genres.

(3) Its re-combinatory compositional process. Mediaeval apocalyptic works typically display a high degree of literary variation in the manuscripts. This variation expresses itself as multiple textual versions or states. The motivation for change is adaptation to local conditions. Its mechanism is the recycling of older material, often in the form of discrete blocks or oracles. The result is the constant creation of new texts (viz., expressions of the same literary work), either in stand-alone form or embedded in other works.

(4) Its distinctive eschatological narrative. Mediaeval apocalyptic speculation features a suite of eschatological expectations that either have their origins in the early mediaeval apocalyptic tradition or else attained their

19 Lorenzo DiTommaso, "Apocryphal Daniel Apocalypses: Works, Manuscripts, and Overview," ETL 94 (2018): 275-316 at 310-12. For a full presentation, see Lorenzo DiTommaso, "The Common Medieval Apocalyptic Tradition," in The Mediaeval Apocalyptic Tradition: From the Twilight of the Roman Empire to the Dawn of Early Modern Europe, ed. Lorenzo DiTommaso and Colin McAllister (Cambridge: Cambridge University Press [forthcoming]).

20 The antiquity of Zoroastrian eschatology remains a controversial topic among authorities. In the present author's view, the eschatology that is preserved in the mediaeval Iranian texts is closer to that of the common mediaeval apocalyptic tradition than the Second-Temple Jewish apocalypses.

21 John J. Collins, The Apocalyptic Imagination: An Introduction to Jewish Apocalyptic Literature, 3rd ed. (Grand Rapids: Eerdmans, 2016), 7-8. See further, Lorenzo DiTommaso, "Revealed Things' in Apocalyptic Literature," in Re-Imagining Apocalypticism: Apocalypses, Apocalyptic Literature, and the Dead Sea Scrolls, ed. Lorenzo DiTommaso and Matthew J. Goff, EJL (Atlanta: SBL Press, 2021 [forthcoming]). 
full development during this time. In addition, these expectations were sequenced in the mediaeval eschatological narrative by means of new periodizing schemata. These schemata, which are central to the subject of this paper, are discussed in the following sections.

(5) Its boundary-crossing ability. The basic homogeneity of the apocalyptic tradition described above translates in social terms to the ability of apocalyptic themes, oracles, and tropes during this period to transcend nearly every boundary - religious, sectarian, linguistic, social, and geographic. Mediaeval apocalyptic speculation was at once Christian, Jewish, and Islamic. It was both high culture and low literature. It appealed to the stakeholder elements and the marginal, and in both secular and spiritual circles. It was deployed by different sides in the same struggle, and for identical reasons. It described both the enemy outside the walls and the enemy within them. And it was used, re-used, and used again, in a tremendous variety of social settings.

Together these five characteristics describe a distinctive type of apocalyptic speculation that was commonplace throughout the mediaeval millennium, and in a profound and meaningful way that transcended region, language, culture, religion, and social class. This speculation was expressed in three main ways. The categorization is primarily organizational, but it is grounded in literary realities:

(1) Stand-alone apocalyptic works. Over 500 such writings are extant. Some stand-alone works are long, extending to ten, twenty, and even thirty pages in a modern book. Others, consisting of only a few oracular stanzas, are shorter. Perhaps two dozen stand-alone works are formal apocalypses, according to the best definition of the genre. The majority are compositionally simpler, such as apocalyptic oracles or prophecies. Related works associated with a specific figure, such as Ezra, the Sibyls, Leo the Wise, and especially Daniel, are common. Such "clusters" denote a measure of literary stability over time, although these elements are subordinate to the re-combinatory compositional process outlined above and regulated by the structure of the mediaeval eschatological narrative. Stand-alone predictions are robustly apocalyptic by nature, in that their primary purposes derive from their revelatory-predictive function and are not subordinate to other functions.

(2) Works that are not stand-alone prophecies, yet are informed by the mediaeval apocalyptic tradition to an equivalently robust degree. These writings typically are more contemplative and compositionally sophisticated than the stand-alone predictions. Their apocalyptic tenor ranges from forte to piano. At the forte end of the spectrum are works whose 
primary purposes are informed by their apocalyptic tenor. These include commentaries on the prophetic and apocalyptic books of the Bible, as well as homilies, liturgical works, dramas, lists, and, above all, tractates on the end-time. Examples of the last type include the Prognosticum futuri saeculi of Julian of Toledo and De Antichristo of Adso Dervensis (Adso de Montier-en-Der). At the piano end are works that similarly are informed by the apocalyptic worldview and oriented by its eschatological horizon yet explore the human condition and are not primarily defined by its revelatory-predictive functions. Augustine's City of God, Dante's Divine Comedy, and Langland's Piers Plowman are prime examples of the type. ${ }^{22}$

(3) Apocalyptic texts and traditions, typically short in length, which are embedded in non-apocalyptic texts, or appear as marginal or intra-linear notes in manuscript folia containing other writings. To this (very) arbitrary collocation of items, one may add non-literary media, such as manuscript illumination, as well as in other graphic forms, ranging from stained glass to fresco to porcelain, even though the majority of these items are late mediaeval in vintage.

All three kinds of material were generated in light of sacred Scripture and occasionally in addition to it. In the mediaeval Christian mentality, "Scripture" meant the Old and the New Testaments, considered holistically, comprehended apocalyptically, and embroidered with extra-canonical texts and traditions. "History" was the story of salvation. It commenced with one creation and culminated with another. Its last phase could be sequenced by the two Danielic schemata (the four empires and the seventy weeks), the three-headed eagle of 4 Ezra, ${ }^{23}$ and/or the thousand-year "millennium" of the Revelation of John. The course of human events within this story was channeled, oriented, and given its ultimate coherence by an eschatological narrative that was oriented by the expected second coming of Jesus Christ.

This eschatological narrative, established by the close of the New Testament era, remained relatively static in the late-antique Christianity. ${ }^{24}$ Although the

22 Kathryn Kerby-Felton, Reformist Apocalypticism and Piers Plowman (Cambridge: Cambridge University Press, 1990), and Claudia Rattazzi Papka, "The Limits of Apocalypse: Eschatology, Epistemology, and Textuality in the Commedia and Piers Plowman," in Last Things: Death and the Apocalypse in the Middle Ages, ed. Caroline Walker Bynum and Paul Freedman (Philadelphia: Pennsylvania University Press, 2000), 233-56 and 351-55.

23 See above, n. 15.

24 The same was true, mutatis mutandis, in Rabbinic Judaism during the same centuries. See Obed Irshai, "Dating the Eschaton: Jewish and Christian Apocalyptic Calculations in Late Antiquity," in Apocalyptic Time, ed. Albert I. Baumgarten, NUm ENss 86 (Leiden: Brill, 2000), 113-53; Uwe Glessmer, "Die 'vier Reiche' aus Daniel in der targumischen Literatur," in The Book of Daniel: Composition and Reception, ed. John J. Collins and Peter W. Flint, 
Devil, the Antichrist, and other figures were fleshed out towards what would become their familiar, three-dimensional forms, nothing strikingly new was added to the basic pattern. The general impulse was to expand or refine figures and tropes, and to redeploy the biblical schemata as required. ${ }^{25}$ This usually took place in the patristic writings, and was prompted by reflections on theodicy and evil, ${ }^{26}$ as opposed to the stand-alone apocalypses of the time (such as the Apocalypse of Paul), which were concerned more with the fate of the soul after death and the nature and inhabitants of the heavenly and infernal realms.

A new eschatological narrative, however, emerged at the close of the late antique period and into the early mediaeval centuries. ${ }^{27}$ Some of the key early texts here are the Sibilla Tiburtina, the Seventh Vision of Daniel, and, above all, the Apocalypse (or Revelations) ${ }^{28}$ of Pseudo-Methodius. The new narrative was anchored by the figure of the Antichrist, ${ }^{29}$ around whom a comprehensive

VTSup 83, FiотL 2, (Leiden: Brill, 2001), 2:468-98; Lawrence H. Schiffman, "Messianism and Apocalypticism in Rabbinic Texts," in The Cambridge History of Judaism: Vol. IV: The Late Roman-Rabbinic Period, ed. Steven T. Katz (Cambridge: Cambridge University Press, 2006), 1053-72; and Geoffrey Herman's contribution to the present volume. On late-antique apocalypticism overall, see Lorenzo DiTommaso, "Il genere 'apocalisse' e l'apocalittico' nella tarda antichità," Rivista di storia del cristianesimo (forthcoming 2020).

25 On the Christian redeployment of the schema of Daniel 9, see William A. Adler, "The Apocalyptic Survey of History Adapted by Christians: Daniel's Prophecy of 70 Weeks," in The Jewish Apocalyptic Heritage in Early Christianity, ed. James C. VanderKam and William A. Adler, CRINT 3.4 (Assen: Van Gorcum; Minneapolis: Fortress Press, 1996), $201-38$.

26 Jeffrey Burton Russell, The Prince of Darkness: Radical Evil and the Power of Good in History (Ithaca: Cornell University Press, 1988), 56-81 and 93-110; and Brian E. Daley, The Hope of the Early Church: A Handbook of Patristic Eschatology (Cambridge: Cambridge University Press, 1991), passim.

27 On the broader social and political contexts, see James T. Palmer, The Apocalypse in the Early Middle Ages (Cambridge: Cambridge University Press, 2014).

28 Although "Apocalypse" is used in this article, the "Revelations" of Pseudo-Methodius is a better title, since the work is not an apocalypse proper, nor does it call itself one. It is an apocalyptic revelation about history and its end. The Syriac title is Mēmrā Composed by the Blessed bar Methodius, Bishop and Martyr, on the Succession of Kings and the End of Time. Mēmrā here means "homily" or "discourse." The titles of the work vary among the Greek and Latin manuscripts.

29 The literature on the mediaeval Antichrist is immense. Seminal works include Wilhelm Bousset, Der Antichrist in der Überlieferung des Judentums, des Neuen Testaments und der alten Kirche (Göttingen: Vandenhoeck and Ruprecht, 1895); Horst D. Rauh, Das Bild des Antichrist im Mittelalter: Vom Tyconius zum deutschen Symbolismus, BGPTM (Münster: Aschendorff, 1973); Richard K. Emmerson, Antichrist in the Middle Ages: A Study of Medieval Apocalypticism, Art, and Literature (Seattle: University of Washington Press, 1981); Bernard McGinn, Antichrist: Two Thousand Years of the Human Fascination with Evil (San Francisco: HarperCollins, 1993); Roberto Rusconi, "Antichrist and Antichrists," 
biography gradually developed, including details about his birth, physical features, and activities in the eschatological age. Also prominent were the expectations for a Last Roman Emperor, ${ }^{30}$ the opening of the Gates of the North and the release of the hordes of Gog and Magog, ${ }^{31}$ and a set series of tribulations and natural disasters that would herald the Last Judgment. These and other expectations were sequenced in the narrative by means of novel periodizing schemata. Most important was the division of history into seven millennia, as in the Apocalypse of Pseudo-Methodius.

This new eschatological narrative is a hallmark feature of the common mediaeval apocalyptic tradition. How, then, was world-history construed within the early part of this tradition, particularly in its schematic periodization, and specifically with reference to the older, four kingdom schema? Was the schema relegated to the fringes of mediaeval historiography, as a subsidiary trope among these new eschatological expectations, or perhaps relevant only in regional ecologies that were located on the centrifugal edges of the old Empire? Or did the schema remain a core component of the mediaeval interpretation of the meaning of history and its end-recycled time and again to fit changing situations?

The evidence suggests a range of answers between these extremes. A full survey of the subject is beyond the remit of an article-length study. Instead, we shall concentrate on three cases that illustrate different ways in which the schema fit into the early mediaeval apocalyptic tradition: (i) the apocryphal Daniel apocalypses, with attention to the Syriac apocalyptica of the seventh and eighth centuries; (ii) the Apocalypse of Pseudo-Methodius and the 70oo-year schema; and (iii) the historiographic construct of translatio imperii in its Western expressions from the eighth through the twelfth centuries. These case-studies also shed light on the schema's two main social functions in its early-mediaeval contexts.

in The Encyclopedia of Apocalypticism: Volume 2: Apocalypticism in Western History and Culture, ed. Bernard McGinn (New York: Continuum, 1998), 287-325; Mariano Delgado and Volker Leppin, eds., Der Antichrist: Historische und systematische Zugänge (Stuttgart: Kohlhammer, 2011); and Lutz Greisiger, Messias-Endkaiser-Antichrist:Politische Apokalyptik unter Juden und Christen des Nahen Ostens am Vorabend der arabischen Eroberung, ОВС 21 (Wiesbaden: Harrassowitz, 2014).

$30 \quad$ Hannes Möhring, Der Weltkaiser der Endzeit, MF 3 (Stuttgart: Thorbecke, 200o); András Kraft, "The Last Roman Emperor Topos in the Byzantine Apocalyptic Tradition," Byzantion 82 (2012): 213-57; and Greisiger, Messias-Endkaiser-Antichrist.

31 Emeri van Donzel and Andrea Schmidt, Gog and Magog in Early Eastern Christian and Islamic Sources (Leiden: Brill, 2012). 


\section{The Four Kingdom Schema in the Early Mediaeval Apocalyptic Tradition}

The common mediaeval apocalyptic tradition may be imagined as a broadly homogeneous environment in which distinctive regional ecologies existed in dynamic flux. Each of these ecologies had its set of idiosyncratic characteristics and was influenced by, and often in competition with, its neighbors.

The primary mechanism of change within this pattern was the need to reinterpret the schema of the four kingdoms in light of present-day events. A major resistance to such change was Rome's status as the fourth kingdom. Insofar as "Rome" existed, in whatever form or fantasy, the end would not come, or at least not in a historiographic schema that had pegged it as the final world empire. A key exegetical anchor here was the belief that the end would be delayed until "the one who now holds it back ... is taken out of the way" (2 Thess 2:7 NRSV), where the restraining power was taken to refer to Rome. ${ }^{32}$

The conviction that Rome was the fourth and final world-kingdom was reinforced by several factors, including the inertial weight of tradition. Imperial Rome remained fresh in the memory of later generations in part because of its sheer size and longevity. Augustine of Hippo (354-430) favored Jerome's identification of the fourth kingdom with Rome, ${ }^{33}$ and where Augustine went, many followed. ${ }^{34}$ In the mediaeval memory, Rome was the paradigmatic Empire,

32 Haimo of Auxerre (d. ca. 865), Expositio in Epistolam II ad Thessalonicenses, re 2:7, Id est hoc solummodo restat, ut Nero, qui nunc tenet imperium totus orbis, tandiu teneat illud donec de medio munditollatur potestas romanorum $=P L 117 \mathrm{col}$. 781. "That is, this alone remains, that Nero, who now holds all authority in the world, will hold it long enough until the power of the Romans is taken from the center of the world." Steven R. Cartwright and Kevin L. Hughes, Second Thessalonians: Two Early Medieval Apocalyptic Commentaries, teams Commentary Series (Kalamazoo: Medieval Institute Publications, 2001), 28-29 (translation theirs). "Nero" is the Emperor reborn as the Antichrist. This "restraining power" was eschatologically relevant when read with 2 Thess $2: 3$, which forecasted a period of "falling away" before the Antichrist would reveal himself; cf. Haimo, op. cit., re 7:7: BESTIA QVARTA TERRIBILIS. Romanorum est imperium omnibus terrenis regnis dissimile. Nomen uero istius bestię idcirco reticetur, ut quidquid terribilius cogitari potest intellegatur; [...] ET HABEBAT CORNVA DECEM. Dicunt in aduentu Antichristi reges DECEM orbem diuisuros romanum = Sumi Shimohara, "Peut-on parler de millénarisme à l'époque carolingienne? L'apport de quelques sources exégétiques," TM 14 (2006): 99-138, citing manuscripts Albi, Médiathèque d'Albi [olim Bм] 31, fols. 61r-72v, Barcelona, Catedral 64, fols. 117rb-124rb, and Torino, Biblioteca Nazionale Universitaria D.V.17, fols. 241v-252v. Augustine, Civ., 20.23: Quattuor illa regna exposuerunt quidam Assyriorum, Persarum, Macedonum et Romanorum. Quam uero conuenienter id fecerint, qui nosse desiderant, legant presbyteri Hieronymi librum in Danielem satis erudite diligenterque conscriptum.

34 Shimohara, "Peut-on parler de millénarisme," with reference to the Latin writers of the eighth and ninth centuries. 
whose imperial majesty dwarfed the "barbarian" states that had sprouted up in the former Imperial provinces like weeds in a palace garden that had been abandoned and gone to seed.

There was the sense, too, that Imperial Rome had absorbed Greece and Greek culture within its vast compass. The Graeco-Roman ideal animated a shared "western" sensibility that did not (and could never) extend farther eastward to include the empires of Egypt or the Ancient Near East. This cultural translatio also went the other way round, in that Greek civilization was broadcast by virtue of Rome and its Empire. (The same was later said for the Empire's role in the spread of Christianity.) As Horace famously wrote, "Captive Greece took captive her fierce conqueror Rome." 35 This concept, later formalized as translatio studii, would prove important to identity-construction in the High Middle Ages.

The post-classical memory of the majesty of Imperial Rome was regularly refreshed by the centripetal desire to "renovate" the Empire (renauatio imperii) via attempts to reconstitute some of its former parts. ${ }^{36}$ That enterprise began with the Emperor Justinian's re-conquest of the Italian peninsula in the middle of the sixth century. ${ }^{37}$ Justinian, of course, was a "Roman," since, unlike the western Empire, the eastern Empire had not collapsed. Its inhabitants continued to refer to themselves as Romans, their Empire as Basileia tōn rhömaiōn, and Constantinople as the "seven-hilled city."38 From the Byzantine standpoint, Constantinople was Rome. ${ }^{39}$ It was as if the Empire had simply picked

35 Graecia capta ferum victorem cepit et artes intulit agresti Latio. Horace, Carm., 2.2.1, lines 156-57 (free translation mine).

36 See, most recently, the essays in Maria Pia Guermandi and Silvia Urbini, eds., Imperiituro: Renovatio imperii: Ravenna nell'Europa ottoniana (Bologna: IBC, 2014); and in Wouter Bracke, Jan de Maeyer, and Jan Nelis, eds. Renovatio, inventio, absentia imperii: From the Roman Empire to Contemporary Imperialism, E B HE 6 (Turnhout: Brepols, 2018).

It arguably lasted until Benito Mussolini's Italian Empire in Africa of late 1930s. Rome (or Rome/Babylon) would become identified with the United States or the European (Economic) Community in modern and contemporary eschatological speculation.

38 Ioannis Stouraitis, "Byzantine Romanness: From Geopolitical to Ethnic Conceptions," in Transformations of Romanness: Early Medieval Regions and Identities, ed. Walter Pohl et al., Millennium Studies 77 (Berlin: Walter de Gruyter, 2018), 123-40. Centuries later, the religious and political heirs of Byzantium would call their capital, Moscow, the "third Rome," the assumption being that a fourth Rome shall never be.

39 GerhardPodskalsky,ByzantinischeReichseschatologie:DiePeriodisierungderWeltgeschichte in den 4. Grossreichen (Daniel 2 und 7) und dem tausendjährigen Friedensreiche (Apok. 20): Eine motivgeschichtliche Untersuchung, Münchener Universitäts-Schriften, Reihe der philosophischen Fakultät 9 (Munich: W. Fink, 1972) is still the starting-point for research on the four kingdom schema in Byzantine political theory. But Paul J. Alexander's criticisms in his review of the volume (Speculum 5o [1975]: 144-45) remain relevant. 
up and moved its headquarters east, to a better and more secure location. Constantinople had inherited Rome's past, and thus also its place in the eschatological future. ${ }^{40}$

The conviction that Constantinople was Rome and that the Eastern Roman Empire was the fourth and final world-kingdom remained at the core of Byzantine political identity throughout the mediaeval millennium. It was articulated in a wide range of apocalyptic writings, both stand-alone and embedded. But the seismic events of the seventh century caused this identification to be questioned, especially in regional contexts. Numerous texts bear witness to this process, including the apocryphal Daniel apocalyptica and the Apocalypse of Pseudo-Methodius. The former are solely a product of the East, while the Apocalypse spanned the common mediaeval apocalyptic tradition in its full geographic scope, East and West.

\subsection{The Apocryphal Daniel Apocalyptica and the Syriac Apocalyptic Tradition}

The corpus of the apocryphal Daniel apocalyptica currently consists of twentyseven writings that are represented in over 100 manuscript copies. ${ }^{41}$ All are pseudonymously attributed to Daniel but were composed during the mediaeval millennium, long after the biblical era. Here "writings" is a more appropriate description than "texts" sensu stricto, since many of these apocalyptica are amalgamations of older oracles and do not always exhibit textual coherence over time as demonstrated in the manuscript evidence. About a third of these writings are formal apocalypses according to the best definition of the literary genre. $^{42}$ The rest are apocalyptic oracles.

The majority of the Daniel apocalyptica are Christian compositions. One Islamic specimen survives, as well as several mediaeval Jewish ones. The primary language of composition was Greek, although examples were also written in or translated into Arabic, Armenian, Coptic, Hebrew, Judaeo-Persian, Latin, Russian, Slavonic, and Syriac.

\footnotetext{
40 Albrecht Berger, "Das apokalyptische Konstantinopel: Topographisches in apokalyptischen Schriften der mittelbyzantinischen Zeit," in Endzeiten: Eschatologie in den monotheistischen Weltreligionen, ed. F. Schmieder and W. Brandes, Millennium Studies 16 (Berlin: Walter de Gruyter, 2008), 135-55.

41 Lorenzo DiTommaso, The Book of Daniel and the Apocryphal Daniel Literature, SVTP 25 (Leiden: Brill, 2005), 89-230, listing twenty-four works, and, more recently, DiTommaso, "Apocryphal Daniel Apocalypses," listing twenty-seven works, with a revised and updated conspectus of the manuscript evidence.

John J. Collins, The Apocalyptic Imagination, 5 .
} 
The Daniel apocalyptica are a phenomenon of the Eastern Mediterranean world and Persia. ${ }^{43}$ This is in contrast to other Byzantine Christian apocalyptic works, such as Apocalypse of Pseudo-Methodius, the Sibilla Tiburtina, and the Oracles of Leo the Wise, which later traveled westward and shaped the Latin apocalyptic tradition.

The relationship among the Daniel apocalyptica is complicated. Each is a discrete work, but circles may be drawn around various groups within the corpus, whose constituents were composed over a span of a thousand years. The earliest extant exemplar, the Seventh Vision of Daniel, dates from the fifth century and the dawn of the mediaeval millennium. Byzantium was the major center of production, especially in the period from the seventh to the ninth centuries, and again after the Crusader sack of Constantinople in 1204. Several Daniel works within the Byzantine circle (which extended to other apocalyptic traditions, especially Slavonic and Armenian $)^{44}$ exhibit one or more shared oracles, the result of their re-combinatory compositional process.

Common elements among the Daniel apocalyptica include their ascription to the biblical prophet ${ }^{45}$ and their overtly historical-eschatological tenor. These two data are related. The figure of Daniel and the revelatory content of the dreams and visions in the biblical book provided the conceptual base for the creation of post-biblical writings under his name. These are Daniel apocalyptica by virtue of their revelatory content as well as in their attribution, and are distinguished in both respects from other "clusters" of writings attributed to the Sibyls, Leo the Wise, Merlin, or Joachim of Fiore. Despite these distinctions, though, all these writings are strongly historical-eschatological in focus, in step with the overall mediaeval apocalyptic tradition.

Another commonality among the Daniel apocalyptica is the fact that they are new predictions, not commentaries on, or interpretations of, the biblical book. What is more, their themes and imagery are more representative of the common mediaeval apocalyptic tradition than their biblical antecedent. The apocryphal Daniel writings are sung in the same key as the biblical book of Daniel, but their melodies are different.

43 Two Latin translations of Greek Daniel oracles are known; both are very late. See DiTommaso, "Apocryphal Daniel Apocalypses," 295 and 297-98.

44 Paul J. Alexander, The Byzantine Apocalyptic Tradition (Berkeley: University of California Press, 1985), and Augostino Pertusi, Fine di Bisanzio e fine del mondo: Significato e ruolo storico delle profezie sulla caduta di Costantinopoli in oriente e in occidente, Nss 3 (Rome: Istituto Storico Italiano per il Medioevo, 1988).

45 A few works are preserved in manuscript copies that are attributed to other figures, such as John Chrysostom. 
One difference is a lack of interest in the four kingdom schemata, which for the most part is not redeployed in the apocryphal works. ${ }^{46}$ As a result, and despite the fact that these Daniel writings are among the core writings of the early mediaeval apocalyptic tradition, they do not reveal much about the use of the four kingdom schema in these centuries.

The outstanding exceptions to the rule are the two Syriac Daniel apocalypses: (i) the Apocalypse of Daniel/Revelation of Daniel the Prophet, which is preserved in two manuscripts; and (ii) the Vision of the Young/Small Daniel, which survives in a single copy. ${ }^{47}$ Each apocalypse recycles imagery from the biblical book to a far greater extent than the other writings in the corpus, and both deploy the four kingdom schema in their reviews of history.

The date of each apocalypse and nature of their textual affiliation are controversial. Sebastian P. Brock's thesis is the most convincing. In his estimation, extensive passages from the Young Daniel also appear in the Syriac Apocalypse of Daniel, and both apocalypses are based on a common source that does not antedate the early seventh century CE. ${ }^{48}$

The seventh century was a volatile and perilous time for Syriac Christians, who were faced first with the successes of Persian Sassanid campaigns against the Byzantine Empire (6o2-622), ${ }^{49}$ and then, more catastrophically, the quicksilver conquest of the Levant by the Arab Muslims $(633-651) .{ }^{50}$ The result was

46 The Vision of the Prophet Daniel on the Emperors was composed in Greek but survives only in Slavonic. It correlates the four kingdoms with eighth-century Byzantine Emperors, though Rome/Byzantium remains the fourth and final kingdom. DiTommaso, "Apocryphal Daniel Apocalypses," 285-86.

47 See DiTommaso, "Apocryphal Daniel Apocalypses," 279-81, for descriptions, manuscripts, and bibliography.

48 Sebastian P. Brock, "The Young Daniel: A Syriac Apocalyptic Text on the End, and the Problem of Its Dating," in Apocalypticism and Eschatology in Late Antiquity: Encounters in the Abrahamic Religions, 6th-8th Centuries, ed. Hagit Amirav, Emmanouela Grypeou, and Guy G. Strousma, LAHR 17 (Leuven: Peeters, 2017), 75-86; and Sebastian P. Brock, "The Small/Young Daniel Re-Edited," in The Embroidered Bible: Studies in Biblical Apocrypha and Pseudepigrapha in Honour of Michael E. Stone, ed. Lorenzo DiTommaso, Matthias Henze, and William Adler, svTP 26 (Leiden: Brill, 2018), 250-84.

49 Lutz Greisiger, "Opening the Gates of the North in 627: War, Anti-Byzantine Sentiment and Apocalyptic Expectancy in the Near East prior to the Arab Invasion," in Peoples of the Apocalypse: Eschatological Beliefs and Political Scenarios, ed. Wolfram Brandes, Felicitas Schmieder, and Rebekka Voß, Millennium Studies 63 (Berlin: Walter de Gruyter, 2016), 63-79.

$5^{\circ}$ On the historical contexts and their relationship to apocalyptic speculation in these centuries, see Stephen J. Shoemaker, The Apocalypse of Empire: Imperial Eschatology in Late Antique and Early Islam (Philadelphia: University of Pennsylvania Press, 2018). On the eschatological valence of Rome in the sources of this period, see Pablo Ubierna, 
an explosion of Syriac apocalyptic writings. ${ }^{51}$ All are historical-eschatological in orientation, including the two Daniel apocalypses ${ }^{52}$ and the Apocalypse of Pseudo-Methodius. ${ }^{53}$ Many employ the four kingdom schema in order to make sense of the seismic shifts of power, now that Rome/Byzantium was no longer the final world-empire.

The political instability of the era is reflected in the identification of the fourth and final world-kingdom. ${ }^{54}$ Writing near the close of the seventh century, the Syriac author of the Apocalypse of Pseudo-Methodius could still imagine the resurgence of Roman (Byzantine) power to overthrow the Sons of Ishmael, or Muslim invaders. For him, Rome remained the fourth world-kingdom. ${ }^{55}$ Over time, though, the possibility of a Byzantine re-conquest diminished as the Ummayid caliphate solidified its control and settled down to the business of

"Recherches sur l'apocalyptique syriaque et byzantine au VIIe siècle: la place de l'Empire romain dans une histoire du salut," BCEMA 2 (2008): 1-28.

$5^{1}$ Cynthia Villagomez, "Christian Salvation through Muslim Domination: Divine Punishment and Syriac Apocalyptic Expectation in the Seventh and Eighth Centuries," ME 4 (1998): 204-18.

$5^{2}$ The special path taken by Syriac Christianity is exhibited in (among other things) a set of distinctive exegetical traditions and a large corpus of apocryphal and apocalyptic writings that included both ancient sources preserved in that language and new ones composed in it.

53 The corpus of stand-alone Syriac apocalyptic works of the seventh and early eighth centuries also includes the Apocalypse of Pseudo-Ephrem, the Edessene Apocalypse, the Apocalypse of Pseudo-Ezra, and the Revelations and Testimonies about the Dispensation of Christ. For summaries, manuscripts, and bibliographic data, see the relevant entries in David Thomas et al., eds., Christian-Muslim Relations: A Bibliographical History: Volume 1 (60o-90o) (Leiden: Brill, 2009). This roster does not include Syriac apocalyptic writings in other genres. Both categories-stand-alone prophecies and apocalyptic works in other genres - are discussed in Witold Witakowski, "Syriac Apocalyptic Literature," in The Armenian Apocalyptic Tradition: A Comparative Perspective: Essays Presented in Honor of Professor Robert W. Thompson on His Eightieth Birthday, ed. Kevork B. Bardakjian and Sergio La Porta, SVTP 25 (Leiden: Brill, 2014), 667-87; and, more panoramically, in Muriel Debié, "Les apocalypses apocryphes syriaques: des textes pseudépigraphiques de l'Ancien et du Nouveau Testament," in Les apocryphes syriaques, ed. Muriel Debié et al., ES 2 (Paris: Geuthner, 2005), 111-46.

54 The Syriac Apocalypse of Ezra repurposes elements of the "Eagle Vision" of 4 Ezra; see Jean-Baptiste Chabot, "L'Apocalypse d'Esdras touchant le royaume des Arabes," RSém 2 (1894): $242-5$ o and $333-46$.

55 See the next section, on "The Apocalypse of Pseudo-Methodius and the 7,ooo-Year Schema" below. The interpretative tradition that God had tasked the Roman Empire to rule the world as the fourth kingdom until the Second Coming is first found in Syriac Christianity in the Demonstrations of Aphrahat (ca. 280-345 CE); see Christopher J. Bonura, "The Roman Empire of the Apocalypse: History, Eschatology, and the Four Kingdoms of Daniel in Late Antiquity, the Early Medieval Middle East, and Byzantium" (PhD diss., University of California, Berkeley, 2019). I am grateful to its author for sending me a copy. 
ruling its subjects. The Revelations and Testimonies about the Dispensation of Christ, which were written a generation after Pseudo-Methodius, still forecasts that the Romans will hand over the Kingdom to God at the end of time. But it de-historicizes the eschaton by unmooring it from human figures and earthly events, making it something more spiritual. ${ }^{56}$ More politically sober is the Gospel of the Twelve Apostles, a work of approximately the same vintage. ${ }^{57}$ Its author could no longer envision an historical end to Islamic rule, ${ }^{58}$ and so added the Sons of Ishmael to the schema. ${ }^{59}$ By the early eighth century, it must have seemed to Syriac Christians that Islam was there to stay, in both its historical and historiographic senses. ${ }^{60}$

\subsection{The Apocalypse of Pseudo-Methodius and the 7,0oo-Year Schema}

Traditional biblical schemata retained a certain degree of traction during the early mediaeval period. The "seventy weeks" of Daniel 9 and the "millennium" of the Revelation of John remained relevant, either in themselves or harmonized with the four kingdom schema, and sometimes in dialogue with other chronological "truffles" that a close reading of Scripture will unearth. The high degree of attention to detail that is associated with this kind of eschatological exegesis is characteristic more of the apocalyptic commentaries, homilies, and similar writings than the stand-alone apocalyptica, which tend to focus on end-time expectations, although there are exceptions.

$5^{6}$ M. Débie, "Muslim-Christian Controversy in an Unedited Syriac Text: Revelations and Testimonies about Our Lord's Dispensation," in The Encounter of Eastern Christianity with Early Islam, ed. Emmanouela Grypeou, Mark N. Swanson, and David R. Thomas (Leiden: Brill, 2006), 225-35.

57 Hans J. W. Drijvers, "The Gospel of the Twelve Apostles: A Syriac Apocalypse from the Early Islamic Period," in The Byzantine and Early Islamic Near East: I. Problems in the Literary Source Material, ed. Averil Cameron and Lawrence I. Conrad, SLAEI 1 (Princeton: Darwin Press, 1992), 189-213.

58 So Drijvers, "The Gospel of the Twelve Apostles," 210-11, contra Gerrit J. Reinink, "A Concept of History," in The Byzantine and Early Islamic Near East: I. Problems in the Literary Source Material, ed. Averil Cameron and Lawrence I. Conrad, SLAEI 1 (Princeton: Darwin Press, 1992), 149-88 at 179-81.

59 Other Syriac authors of the era were equally sanguine in their responses to the winds of political change. Pseudo-Ephrem and John of Phenek reworked the schema to accommodate the shifts in power, Persian Sassanid or Arab Muslim. See Wido Th. van Peursen, "Daniel's Four Kingdoms in the Syriac Tradition," in Tradition and Innovation in Biblical Interpretation: Studies Presented to Professor Eep Talstra on the Occasion of His Sixty-Fifth Birthday, ed. Wido Th. van Peursen and Janet W. Dyk, ssN 57 (Leiden: Brill, 2011), 189-207, at $190-91$.

6o Villagomez, "Christian Salvation," 218; and Peursen, "Daniel's Four Kingdoms," 193-94. 
Alongside such traditional schemata appeared a slew of new mediaeval patterns. One early example is the schema of the ten suns of the Sibilla Tiburtina. The lost Greek original of this work dates to the end of the fourth century or fifth century $\mathrm{CE}$, and is among the first mediaeval apocalyptic writings. ${ }^{61}$ Anke Holdenried's study of the Latin versions of this work demonstrates its centrality in Western Europe from the twelfth century onward. ${ }^{62}$

Another historiographic framework that would later enjoy immense popularity in the West was the three "states" of the Calabrian abbot Joachim of Fiore $\left(1135^{-1202)} .^{63}\right.$ More to the East, the schema of the nineteen kings or kingdoms structured several works within the Coptic apocalyptic milieu, including the Fourteenth Vision of Daniel. ${ }^{64}$

The most important new historiographic pattern to emerge in the early mediaeval period, however, was the seven-millennia schema of the Apocalypse of Pseudo-Methodius. This work was composed by an anonymous Syriac monk near the end of the seventh century, in the wake of the Muslim onslaught. ${ }^{65}$ It was swiftly translated from Syriac into Greek, ${ }^{66}$ and then again from Greek

61 Paul J. Alexander, The Oracle of Baalbek: The Tiburtine Sibyl in Greek Dress, Dos 10 (Washington, DC: Dumbarton Oaks Center for Byzantine Studies, 1967). Recent English translations of the Greek and Latin texts: Rieuwerd Buitenwerf, "The Tiburtine Sibyl (Greek)," in Old Testament Pseudepigrapha: More Noncanonical Scriptures: Volume 1, ed. Richard Bauckham, James R. Davila, and Alexander Panayotov (Grand Rapids: Eerdmans, 2013), 176-88; and Stephen J. Shoemaker, "The Tiburtine Sibyl: A New Translation and Introduction," in New Testament Apocrypha: More Noncanonical Scriptures: Volume 1, ed. Tony Burke and Brent Landau (Grand Rapids: Eerdmans, 2016), 510-25.

62 Anke Holdenried, The Sibyl and Her Scribes: Manuscripts and Interpretation of the Latin Sibylla Tiburtina c. 1050-1500 (Aldershot: Ashgate, 2006).

63 The contributions in Matthias Riedl, ed., A Companion to Joachim of Fiore, всCт 75 (Leiden: Brill, 2018), are a fine port of entry into the topic. See also the "Conclusions" below.

64 Jos van Lent, "The Proto-Fourteenth Vision of Daniel," in Christian-Muslim Relations: A Bibliographical History: Volume 1 (6oo-9oo), ed. David Thomas et al. (Leiden: Brill, 2009), 309-13; and Jos van Lent, "The Fourteenth Vision of Daniel," in Christian-Muslim Relations. A Bibliographical History: Volume 3 (1050-1200), ed. David Thomas et al. (Leiden: Brill, 2011), 697-703.

65 The Syriac text survives in one complete manuscript and several partial copies. The standard edition is Gerrit J. Reinink, Die syrische Apokalypse des Pseudo-Methodius, Csco 54O-41, SS 220-21 (Leuven: Peeters, 1993).

66 Anastasios Lolos, Die Apokalypse des Ps.-Methodios, BZKP 83 (Meisenheim: Hain, 1976); and Anastasios Lolos, Die dritte und vierte redaktion des Ps.-Methodios, BZKP 94 (Meisenheim: Hain, 1978). Four recensions of the Greek text are known. The extant manuscripts are all relatively late. A new edition of the Greek manuscript copies of the Apocalypse of Pseudo-Methodius is a desideratum. Approximately 75 manuscripts beyond those that Lolos lists in his volumes contain all or part of the text. I have seen about 
into Latin. Thus, by the first half of the eighth century, the Apocalypse of Pseudo-Methodius was circulating widely in both the East and the West.

The Apocalypse of Pseudo-Methodius encapsulates the common mediaeval apocalyptic tradition in all respects, including its historical-eschatological focus and its distinctive eschatological narrative, which it did much to fashion. The text describes the history of the world, beginning with the expulsion of Adam and Eve from the Garden of Eden and culminating in the second coming of Christ. This retelling is unremarkable: revisions of all or parts of the biblical record are as old as the Bible itself (cf. 1-2 Chronicles).

What is extraordinary is the way that its author structured the history of the world into seven millennia, each millennium corresponding to one day of creation. The underlying presumption, based on Scripture, is that one day for God is like a thousand years for humanity. ${ }^{67}$ The 7,000-year schema did not originate with the Apocalypse of Pseudo-Methodius. ${ }^{68}$ But the influence of the work, by virtue of its many translations and versions, made it the principal vehicle for the schema's transmission. ${ }^{69}$

The Apocalypse's description of the first six millennia of the world (chapters 1-10) consists of an idiosyncratic and highly abbreviated retelling of Old Testament history, followed by an account of the Macedonian king, Alexander the Great, and his successors. Although its author focuses on chronology and genealogy, he never lets the eschatological horizon get too far out of sight.

The dawn of the seventh millennium heralds the beginning of the end-time (chapters 11-14), which is structured in part by the seventy-week schema of Daniel 9. As with all apocalyptic writings, the events of last days are considered to be foreordained and part of the divine plan. The eschatological curtain rises when "Persians" (the Sassanid Empire) are uprooted by the "seed of Ishmael" (the Arab Muslims). After causing great devastation and much tribulation, the Ishmaelites are conquered by the Last Roman Emperor, who pacifies the world. This golden time is shattered when the Gates of the North open and

a quarter of this number; the rest remain subject to verification by autopsy. The texts of some of these manuscripts have already been published.

67 Cf. Ps 9o:4, which is accorded an apocalyptic valence in 2 Pet 3:8.

68 Richard Landes, "Lest the Millennium Be Fulfilled: Apocalyptic Expectations and the Pattern of Western Chronography 100-80o CE," in The Use and Abuse of Eschatology in the Middle Ages, ed. Werner Verbeke, Daniel Verhelst, and Andries Welkenhuysen, ML 15 (Leuven: Leuven University Press, 1988), 137-211, esp. 161-65.

69 Compare Beatus of Liebana (ca. 730-ca. 80o), Commentaria in Apocalypsin (ca. 776?), book IV, which also segments the biblical record into seven ages. Their start- and end-dates, however, are not the same as those of Pseudo-Methodius. Critical edition: E. Romero-Pose, ed., Sancti Beati a Liebana Commentarius in Apocalypsin, 2 vols. (Rome: Typis Officinae Polygraphicae, 1985). 
the hordes of Gog and Magog are released. After their defeat, the Antichrist, Son of Perdition appears. The Roman Emperor travels to Golgotha and places his crown on the Holy Cross, which ascends to heaven. The Son of Perdition enters Jerusalem and performs miracles, deceiving all. He sits in the Temple as a god, but is shamed and denounced by Enoch and Elijah. The Apocalypse of Pseudo-Methodius closes with the return of Christ, the destruction of the Antichrist, and the Final Judgment.

The era of Alexander the Great in chapter 8 is introduced with an account of the four world-kingdoms: ${ }^{70}$

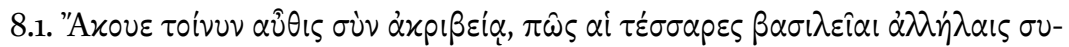

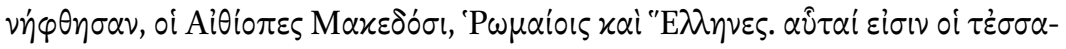

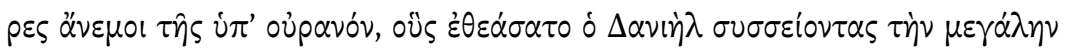
$\theta \dot{\alpha} \lambda \alpha \sigma \sigma \alpha \nu .{ }^{71}$

8.1. Audi igitur nunc certisseme, quomodo quatuor haec regna convenierunt sibi: aethiopes enim macedonis et romanis greci. Haec sunt quattuor uenti $<\ldots>$ cummouentes mare magnum. ${ }^{72}$

The sequence is remarkable in several respects. Ethiopia, rather than the traditional Babylon, is presented as the first kingdom, while Macedon is the second kingdom, rather than Media-Persia. Also, Ethiopia and Macedon are "united" with each other, as are the third and fourth kingdoms, Greece and Rome.

The alterations to the schema are the key to its function in the late-seventhcentury Syrian context of the Apocalypse of Pseudo-Methodius. At issue was whether Jesus had a single divine or human/divine "nature" (a theological stance called miaphysitism) or if he manifested his divine and human natures separately (dyaphysitism).

70 There are slight differences and mistranslations, but the Greek Recension I is a close rendering of the Syriac text, with a notable interpolation at 13.7-10. Similarly, the Latin Recension I is a close translation of the Greek Recension I.

71 "So hear again precisely how the four kingdoms were united with each other, the Ethiopians with the Macedonians, and the Greeks with the Romans. These are the four winds under heaven, which Daniel saw disturbing the great sea" (text and translation: Benjamin Garstad, Apocalypse of Pseudo-Methodius: An Alexandrian World Chronicle, DOML 14 [Cambridge, MA: Harvard University Press, 2012], 22-23). The biblical reference is to Dan 7:2.

72 "So hear now most certainly how these four kingdoms came together among themselves, the Ethiopians with the Macedonians and the Greeks with the Romans. These are the four winds $<\ldots>$ disturbing the great sea" (text and translation: Garstad, Apocalypse of Pseudo-Methodius, 96-97). This portion of the text is reproduced in the two main Latin Recensions, I and II. 
Syriac Christianity is miaphysite, but the Byzantine Greeks were dyaphysites. It was imperative, therefore, for the miaphysite Syriac author ${ }^{73}$ of the Apocalypse of Pseudo-Methodius to demonstrate that recent events were in step with the divine plan for history and in line with the theological stance of his community.

He did this in extraordinary fashion. First, he grafted the four kingdom schema onto the root of the miaphysite kingdom of Ethiopia ${ }^{74}$ by identifying Alexander's mother as an Ethiopian princess named Chuseth (8.2) $\cdot{ }^{75} \mathrm{Her}$ union with Alexander's father, Philip of Macedon, explains how the kingdoms of Ethiopia and Macedon became "united." Second, he forecast that the eschatological figure of the Last Roman Emperor would march forth "from the sea of Ethiopia" (13.11). This shifted the nexus of salvation history to the kingdom of Ethiopia and closed the historical loop that began with the mixing of the kingdoms of Ethiopia and Greece in the person of Alexander.

The insertion of monophysite Ethiopia as the first kingdom of the schema anchored the author's Christological position vis-à-vis his Syriac co-religionists who favored the diaphysite (Chalcedonian) view. At the same time, the Muslim triumph served notice of divine punishment wrought on the immoral-and diaphysite—Byzantine emperors:

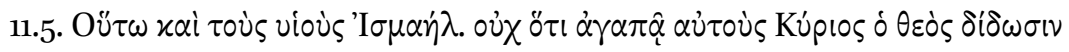

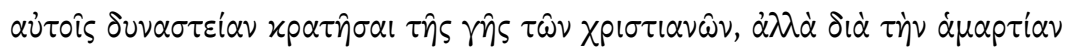

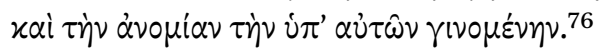

11.5. Sic etenim filios Ismael, non quod eos diligat dominus Deus, dabit eis potentiam hanc, ut obteneant terram christianorum, sed propter peccatum et iniquitatem, quae ab eis committitur. ${ }^{77}$

73 The monophysite identity of the author is supported by other evidence, such as the attestation that "Methodius" received his revelation on Mount Senegar (Jebel Singar), a monophysite stronghold.

74 His interpretative key was probably Ps 68:31b: "Let Ethiopia hasten to stretch out its hands to God" (NRSv) or, in the Syriac Peshitta, "Kush will surrender to God." "Kush" appears in the Hebrew (мт) version, "Ethiopia" in the Greek (LXX 67:32b).

75 Christine Stöllinger-Löser, "Chuseth, Pseudo-Methodius und Rudolf von Ems: Wer war die Mutter Alexanders des Großen," AssL 155 (2003): 347-54.

76 "Just so with the Sons of Ishmael. Not because the Lord God loves them does he give them power to conquer the land of the Christians, but because of the sin and the lawlessness which have been brought into being by them" (text and translation: Garstad, Apocalypse of Pseudo-Methodius, 38-39).

77 "Just so with the Sons of Ishmael, it is not because the Lord God loves them will he give them this power that they should conquer the land of the Christians, but because 
This is not to say that the author of the Apocalypse of Pseudo-Methodius either desired or expected the Muslims to remain in power. As the quotation asserts, God does not love the Sons of Ishmael. Their imminent captivity, death, and ruin are foreordained at the hands of the Last Roman Emperor. Gerrit Reinink understands this anti-Muslim stance as a reply to the seventh-century Armenian archbishop (Pseudo-) Sebeos, who regarded the Arab Muslims as the new fourth and final kingdom. ${ }^{78}$ This is possible, but the rationale for the expectation need not be sought beyond the general hope for a Christian triumph at the end of time. Reinink is correct, though, in that an overarching purpose of Apocalypse was to forestall the conversion of Syriac Christians to the religion of their new Muslim overlords. ${ }^{79}$

The Apocalypse of Pseudo-Methodius traveled westward in the early eighth century. There, in Latin Christendom, it became part of another apocalyptic tradition, one in which the four kingdom schema of Daniel was used to reinforce the present order rather than to forecast radical eschatological upheaval.

\subsection{Translatio imperii and the West in the Early Mediaeval Centuries}

As mentioned, the Byzantines considered themselves to be Romans in every respect. From their point of view, the Empire had not fallen. It had merely relocated its base of operations from Rome to Constantinople, on the eastern side of the Mediterranean basin. Accompanying it were notions of the translatio imperii, Rome as the fourth empire,,$^{80}$ and Constantinople's place in the eschatological drama that was expected to play out.

This was not the perspective of the Latin Christians in the aftermath of the collapse of the Western Empire. ${ }^{81}$ They were, of course, too busy dealing with

of the sin and lawlessness that are committed by them" (text and translation: Garstad, Apocalypse of Pseudo-Methodius, 110-13). This portion of the text is not reproduced in Latin Recension II.

78 Reinink, "Pseudo-Methodius," 157-58.

79 Reinink, "Pseudo-Methodius." See also the "Conclusions" below.

8o Paul Magdalino demonstrates that the imperial assimilation of Christian eschatology began with Constantine in the early fourth century; see "The History of the Future and its Uses: Prophecy, Policy and Propaganda," in The Making of Byzantine History: Studies Dedicated to Donald M. Nicol on his Seventieth Birthday, ed. Roderick Beaton and Charlotte Roueché (Aldershot: Variorum, 1993), 3-34.

81 Nor, it should be said, was it that of Jews of the same era. On the four kingdom schema in Jewish apocalyptic works of mediaeval period, see Norman Roth, Jews, Visigoths and Muslims in Medieval Spain: Cooperation and Conflict, MIPTS 10 (Leiden: Brill, 1994), 205-14; and W. J. van Bekkum, "Four Kingdoms Will Rule: Echoes of Apocalypticism and Political Reality in Late Antiquity and Medieval Judaism," in Endzeiten: Eschatologie in den monotheistischen Weltreligionen, ed. Wolfram Brandes and Felicitas Schmieder, Millennium Studies 16 (Berlin: Walter de Gruyter, 2008), 101-18. 
the aftermath of the apocalypse that had already occurred to worry about the nuances of the one that was to come.

Gradually, as society began to reconstitute itself, the new states in Western Europe began to think of themselves as heirs to Imperial Rome. These states were runty by ancient standards, yet still "kingdoms" by the measure of their own time. But it was only when Pope Leo III crowned Charlemagne imperator romanorum ("Emperor of the Romans") on Christmas Day in the year 800 that the claim to imperial inheritance could be fairly made. ${ }^{82}$ Charlemagne's coronation revivified the fourth kingdom, retarded the appearance of the Antichrist, and reasserted the western claim to the imperial mantle, a claim that the Byzantine Emperor Michael I recognized twelve years later. The coronation also initiated an imperial competition with Constantinople-das Zweikaiserproblem - that culminated with the sack of that city during the Fourth Crusade in 1204 and terminated with the final Ottoman conquest of the Eastern Empire in $1453{ }^{83}$

Underpinning Charlemagne's imperial claim was the mediaeval political concept of translatio imperii, or the serial transfer of imperium from kingdom to kingdom until the time of the end. ${ }^{84}$ The classical Roman use of imperium as an

82 For the context, see Owen Phelan, The Formation of Christian Europe: The Carolingians, Baptism and the Imperium Christianum (Oxford:Oxford University Press, 2014). Carolingian iconography made frequent use of Roman imperial models; see Karl F. Morrison, with Henry Grunthal, Carolingian Coinage, Numismatic Notes and Monographs 158 (New York: American Numismatic Society, 1967).

83 See A. Lamma, "Il problema dei due imperi e dell'Italia meridionale nel giudizio delle fonti letterarie dei secoli IX eX," in Atti del $3^{\circ}$ Congresso internazionale di studi sull'alto Medioevo (Benevento-Montevergine-Salerno-Amalfi, 14-18 ottobre 1956) (Spoleto: Presso la sede del Centro di studi, 1959), 154-253; and Constantine N. Tsirpanlis, "Byzantine Reactions to the Coronation of Charlemagne (78o-813)," Byzantina 6 (1974): $345^{-60}$, for the "twoemperor" competition during its early phase.

84 Giuseppe Martini, "Traslatione dell'Impero e donazione di Costantino nel pensiero e nella politica d'Innocenzo III," Archivio della Società romana di storia patria 56/57 (1933/34): 219-362; Werner Goez, Translatio imperii: Ein Beitrag zur Geschichte des Geschichtsdenkens und der politischen Theorien im Mittelalter und in der frühen Neuzeit (Tübingen: Mohr, 1958); Josef Fleckenstein, "Zum mittelalterlichen Geschichtsbewußtsein," in Archäologie und Geschichtsbewußtsein, ed. Hermann Müller-Karpe (Munich: C. H. Beck, 1982), 53-67; Franz-Josef Schmale, Funktion und Formen mittelalterlicher Geschichtsschreibung: Eine Einführung (Darmstadt: Wissenschaftliche Buchgesellschaft, 1985); and, more generally, Werner Goez, "Die Danielrezeption in Abendland: Spätantike und Mittelalter," in Europa, Tausendjähriges Reich und Neue Welt: Zwei Jahrtausende Geschichte und Utopie in der Rezeption des Danielbuches, ed. Mariano Delgado, Klaus Koch, and Edgar Marsch (Freiburg: Universitätsverlag; Stuttgart: Kohlhammer, 2003), 176-97; Tamás Nótári, "Translatio imperii-Thoughts on Continuity of Empires in European Political Traditions," AJH $5^{2}$ (2011): $146-56$, is a useful overview. 
invested power in a human figure is instructive in this regard. ${ }^{85}$ But the specific application of the translatio in its formal historiographic sense is more directly informed by the four kingdom schema. The locus classicus here is Daniel 2, where the monarchs are correlated to their sovereign kingdoms or empires, represented by the sequence of metals of diminishing value. "You, $\mathrm{O}$ king ... you are the head of gold" (2:37-38, NRSv), so Daniel says to Nebuchadnezzar, interpreting the king's dream. The theological threads stitching the classical and biblical traditions together were spun a few centuries later by patristic writers, where the idea of a king as the earthly imitatio of God was fused with the concept of an emperor who was divinely appointed and sovereign. ${ }^{86}$

The utility of the translatio imperii in the early mediaeval West was not restricted to its Carolingian application. ${ }^{87}$ The schema was repurposed in Iberia, ${ }^{88}$ Wessex ${ }^{89}$ and Normandy. ${ }^{90}$ The process in its totality may be understood as the attempt to re-channel the translatio imperii to regional dynasties.

85 The Romans also understood the shift of political power and military might on the corporate level, in this case from the Greek world to their own. See above, n. 12, regarding Polybius.

86 Gerbern S. Oegema, "Die Danielrezeption in der alten Kirche," in Europa, Tausendjähriges Reich und Neue Welt: Zwei Jahrtausende Geschichte und Utopie in der Rezeption des Danielbuches, ed. Mariano Delgado, Klaus Koch, and Edgar Marsch (Freiburg: Universitätsverlag; Stuttgart: Kohlhammer, 2003), 84-104; and Giuseppe Zecchini, "Latin Historiography: Jerome, Orosius and the Western Chronicles," in Greek and Roman Historiography in Late Antiquity: Fourth to Sixth Century A.D., ed. Gabriele Marasco (Leiden: Brill, 2003), 317-45.

87 Goez, Translatio imperii; and Stelian Brezeanu, "Translatio imperii' und das lateinische Kaiserreich von Konstantinopel," RevRo 14 (1975): 607-17.

88 Rodrigo Furtado, "The Chronica Prophetica in MS. Madrid, RAH Aem. 78," in Forme di accesso al sapere in età tardoantica e altomedievale: raccolta delle relazioni discusse nell'incontro internazionale di Trieste, Biblioteca Statale, 24-25 settembre 2015, ed. Lucio Cristante and Vanni Veronesi, Polymnia 19 (Trieste: Edizioni Università di Trieste, 2016), 75-100. According to Furtado, the addition of Orosius's work to the version of the Chronica prophetica in the "Roda codex" (Madrid, Real academia de la Historia, 78) in the eleventh century signals the integration of translatio imperii of the Prophetica within the broader context of world history in its Iberian context. Pablo Ubierna's examination of the abbreviated version of the Apocalypse in the same manuscript does not bear on our study, although he suggests that it was translated directly from the Syriac, without an intermediary Greek or Latin Recension I or II vector; see his article, "Byzantine Greek Apocalypses and the West: A Case Study," in Apocalypticism and Eschatology in Late Antiquity: Encounters in the Abrahamic Religions, 6th-8th Centuries, ed. Hagit Amirav, Emmanouela Grypeou, and Guy G. Strousma, LAHR 17 (Leuven: Peeters, 2017), 205-18, at 214-15.

89 Francis Leneghan, "Translatio Imperii: The Old English Orosius and the Rise of Wessex," Anglia 133 (2015): 656-705.

90 Benjamin Pohl, "Translatio imperii Constantini ad Normannos: Constantine the Great as a Possible Model for the Depiction of Rollo in Dudo of St. Quentin's Historia Normannorum," Millennium: Yearbook on the Culture and History of the First Millennium 9 (2012): 299-342. 
Unfortunately the Latin Apocalypse of Pseudo-Methodius ${ }^{91}$ sheds only a litthe light on this process, despite the fact that over 200 manuscript copies of all or parts of the work are extant, including a few that date from the eighth century, i.e., only a few generations removed from the composition of the Syriac original. ${ }^{92}$ The manuscripts demonstrate several recensions of the Latin text, of which Recensions I and II are the most important, plus several abbreviated versions. The problem is that there is no satisfactory study of the Latin text in its entirety, and in particular of each manuscript in view of its recension, date, and place of production, which might in turn illuminate how its features (such as the four kingdom schema) were adapted to regional conditions. ${ }^{93}$ In other words, we have an excellent snapshot of the broadcast transmission of the text in the West, but our picture lacks the fine resolution that is necessary to make out its details.

Despite this lack of clarity, a few points stand out. Willem J. Aerts and George A. A. Kortekaas have observed that the Latin Recension II deemphasizes the four kingdoms. ${ }^{94}$ Recension II also substitutes the title "King of the Christians and the Romans" (rex christianorum et romanorum) for the

91 Ernst Sackur, Sibyllinische Texte und Forschungen: Pseudomethodius, Adso und die Tiburtinische Sibylle (Halle a.d. Saale: M. Niemeyer, 1898); and W. J. Aerts and G. A. A. Kortekaas, Die Apokalypse des Pseudo-Methodius: Die ältesten griechischen und lateinischen Übersetzungen, CSCO 569-70, ss 97-98 (Louvain: Peeters, 1998). See also the manuscript conspectus of Marc Laureys and Daniel Verhelst, "Pseudo-Methodius, Revelationes: Textgeschichte und kritische Edition: Ein Leuven-Groninger Forschungsprojekt," in The Use and Abuse of Eschatology in the Middle Ages, ed. Werner Verbeke, Daniel Verhelst, and Andries Welkenhuysen, ML 15 (Leuven: Leuven University Press, 1988), 112-36. The Greek and Latin texts in Aerts and Kortekaas's edition are reproduced, with English translations, in Garstad, Apocalypse of Pseudo-Methodius.

92 O. Prinz, "Eine frühe abendländische Aktualisierung der lateinischen Übersetzung des Pseudo-Methodius," DAEM 41 (1985): 1-23; T. Frenz, "Textkritische Untersuchungen zu 'Pseudo-Methodios': Das Verhältnis der griechischen zur ältesten lateinischen Fassung," ByzZ 8o (1987): 50-58; and Michael W. Herren, "The 'Revelationes' of Pseudo-Methodius in the Eighth Century," in Felici curiositate: Studies in Latin Literature and Textual Criticism from Antiquity to the Twentieth Century in Honour of Rita Beyers, ed. Guy Guldentops, Christine Laes, and Gert Partoens, IPM 75 (Turnhout: Brepols, 2017), 409-18.

93 Lorenzo DiTommaso, "The Apocalypse of Pseudo-Methodius: Notes on a Recent Edition," MEG 17 (2017): 311-21. The Latin recensions of the Apocalypse were continuously copied for the next 5 oo years after Adso. It would be interesting to discover whether manuscripts that were copied in the same region preserve distinctive variations in their historical identifications, including the identity of the fourth empire. James T. Palmer and I are preparing a study of the Latin and western vernacular texts and traditions of the Apocalypse based on a fresh examination of the manuscripts. One objective of our study is to chart the regional trajectories of the versions.

Aerts and Kortekaas, Die Apokalypse des Pseudo-Methodius, 31-35. 
"King of the Greeks, that is, the Romans" in the texts of Greek Recension I

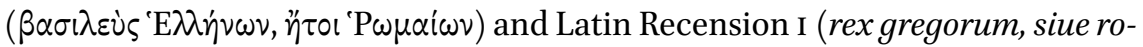
manorum) at 13.11. Matthew Gabriele suggests that the switch indicates a mental shift in the political ideology in the West. ${ }^{95}$ But this and other points must remain provisional pending a comprehensive examination of the manuscripts.

What is clear is that the Frankish kingdoms were a locus of manuscript production of the Latin Apocalypse in the centuries after Charlemagne. This region was also the focus of the translatio imperii over the same time, when various Frankish rulers were grafted onto the four kingdom schema as heirs to the Roman Emperors of old.

Sometimes the new stock was of inferior quality. Notker I of St. Gall (ca. 840-912), ${ }^{96}$ saw in the Emperor Charles III (839-888, r. 881-887) a figure greater than his illustrious great-grandfather Charlemagne. Charles was the Danielic head of gold, the progenitor of the new main branch sprouting from the old Roman root. ${ }^{97}$ Yet by the time of his death, the torpid and incompetent Charles had been deposed, Charlemagne's empire shattered, and the Frankish branch forever divided.

Other Frankish monarchs were made of heartier material. In East Francia, Otto I of Saxony (912-973) was crowned in Rome in the year 962 as Emperor of the Romans and the Franks. The additional title is significant. Otto had unified the German duchies, conquered the Kingdom of Italy, and legitimately could be considered a "savior of Christianity" after crushing the pagan Magyars at Lechfeld.

In 996, Otto I's sixteen-year-old grandson Otto III (980-10o2) was himself crowned "Holy Roman Emperor" (Sacrum romanum imperium), again in Rome. ${ }^{98}$ His friend and teacher, Gerbert d'Aurillac (ca. 946-10o3), later Pope Sylvester II, phrased the young Emperor's campaigns in terms of "renewing the Roman empire" (renouatio imperii romanorum). Seventy years later, Adam of

95 Matthew Gabriele, An Empire of Memory: The Legend of Charlemagne, the Franks, and Jerusalem before the First Crusade (Oxford: Oxford University Press, 2011), 108-9 (translation mine). See DiTommaso, "The Apocalypse of Pseudo-Methodius," 316, for comments.

96 Called Balbulus ("the Stammerer").

97 Omnipotens rerum dispositor ordinatorque regnorum et temporum ... alterius non minus admirabilis statue caput aureum per illustrem Karolum erexit in Francis. Notker, Gesta, I.1 = Hans F. Haefele, ed., Notker der Stammler, Taten Kaiser Karls des Großen: Notkeri Balbuli Gesta Karoli Magni imperatoris, MGHSRG (Berlin: Weidmann, 1959), 1. A seal preserved in Bayerisches Nationalmuseum, Munich, depicts Charles III in profile as a Roman emperor. He wears a Roman-style cloak (pallium), fastened by a large jewel at the nape, and a laurel wreath encircles his head. The seal bears the inscription KARLOvs MAG[NV]s ("Charles the Great").

98 David A. Warner, "Ideals and Action in the reign of Otto III," JMedHist 25 (1998): 1-18. 
Bremen could argue that the Frankish Germans had inherited Rome's fourthkingdom status through the Ottonian line. ${ }^{99}$

At the same time, in West Francia, Queen Gerberga (ca. 913/914-969 or 984) asked Adso (ca. 910/920-992), Abbot of the Benedictine monastery of Montier-en-Der, for a précis regarding the nature and expectations surrounding the figure of the Antichrist. Perhaps Gerberga was motivated by the approaching millennial year 1000. ${ }^{100}$ Adso's response to the Queen was in the form of a letter, "On the Origin and Time of the Antichrist" (De ortu et tempore Antichristi), ${ }^{101}$ which summarized the data that he had gathered about the appearance, nature, and actions of the expected Son of Perdition. ${ }^{102}$ It became one of the most influential apocalyptic works of the Middle Ages in the West.

Although Adso used the Apocalypse of Pseudo-Methodius, which he knew in its Latin translation, he did not include a record of the history of the world in his reply to the Queen, nor did he pseudonymously ascribe it to an authoritative figure from the past. His letter is not an apocalyptic forecast but a compendium of eschatological traditions. Its contents are sifted, sieved, and sorted like a learned essay and structured like a hagiography. ${ }^{103}$ In this manner, Adso's letter established the model of a Vita Antichristi ("Life of the Antichrist") that would persist over the next six centuries, beyond the era of the manuscript and into the age of the early print- and block-books.

99 Ipse enim, ut in Gestis suis legitur, apostolicae sedis auctoritate fultus, legationem ad gentes suscepit, Teutonumque populos, apud quos nunc et summa imperii Romani et diuini cultus reuerentia uiget ac floret, ecclesiis, doctrina uirtutibusque illustrauit. Adam of Bremen, Gesta Hammaburgensis ecclesiae pontificum, ex rescensione Lappenbergii, MGH ss rer. Germ. 1.11 (Hannover: Hahn, 1876), 8. Cf. Len Scales, The Shaping of German Identity: Authority and Crisis, 1245-1414 (Cambridge: Cambridge University Press, 2012), 282, n. 120.

100 The year 1000 was an eschatologically auspicious date that may or may not have occasioned great apocalyptic anxiety among Christians. Scholars are of two minds on this matter. Richard Landes is probably the foremost proponent of the view that it did cause much anxiety. See the papers in Richard Landes, Andrew Gow, and David C. Van Meter eds., The Apocalyptic Year 10oo: Religious Expectation and Social Change, 950-1050 (Oxford: Oxford University Press, 2003). A better model accommodates both positions.

101 Daniel Verhelst, Adso Dervensis, De ortu et tempore Antichristi, necnon et tractatus qui ab eo dependunt, СсСм 45 (Turnhout: Brepols, 1976).

102 Richard K. Emmerson, "Antichrist as Anti-Saint: The Significance of Abbot Adso's Libellus de Antichristo," AmBR 30 (1979): 175-19o; and Volker Leppin, "Der Antichrist bei Adso von Montier-en-Der," in Der Antichrist: Historische und systematische Zugänge, ed. Mariano Delgado and Volker Leppin (Stuttgart: Kohlhammer, 2011), 125-36.

103 R. Konrad, De ortu et tempore Antichristi: Antichristvorstellung und Geschichtsbild des Abtes Adso von Montier-en-Der (Kallmünz: M. Lassleben, 1964), esp. 16-25; and Emmerson, "Antichrist as Anti-Saint," passim. 
Adso hewed to the traditional interpretation of Daniel 2, read in light of the "restraining power" of 2 Thessalonians. Like Notker of St. Gall three generations before him, Adso re-positioned the interpretation in a western sequence that began with Charlemagne's assumption of the Imperial mantle. Unlike Notker, however, Adso wrote in an era when the Carolingian dream no longer corresponded to political reality. The map of Latin Christendom had changed for Adso and the west Franks, as it had done for Gerbert d'Aurillac and Adam of Bremen among the east Franks.

This change is manifested in Adso's letter, which was addressed to the Queen of France, not the Pope in Rome or the Emperor in Constantinople. In other words, it was colored by regional circumstances. One such circumstance was Gerberga's position as the wife of Louis IV, and reflects the self-identity of their court circle and her keen interest in monastic reform, whose champions characterized their opponents as "Antichrists." 104 It is partly in this context that Adso's letter must be regarded.

His letter was also part of a co-ordinated effort to normalize Louis's rule in a period of extraordinary political flux. Adso made explicit the geographic shift that had been implicit in Charlemagne's coronation by altering the references to the Last Roman Emperor in the Latin Apocalypse of Pseudo-Methodius to reges francorum, that is, the kings of his own West Francia:105

Inde ergo dicit Paulus apostolus, Antichristum non antea in mundum esse uenturum, nisi uenerit discessio primum, id est, nisi prius discesserint omnia regna a romano imperio, que pridem subdita erant. Hoc autem tempus nondum uenit, quia, licet uideamus romanum imperium ex maxima parte destructum, tamen, quandiu reges francorum durauerint, qui romanum imperium tenere debent, romani regni dignitas ex toto non peribit, quia in regibus suis stabit. ${ }^{106}$

104 Simon MacLean, "Reform, Queenship and the End of the World in Tenth-Century France: Adso's 'Letter on the Origin and Time of the Antichrist' Reconsidered," RBPH 86 (2008): $645^{-75}$.

105 MacLean, "Reform, Queenship," 103-14, 144-45; and B. Schneidmüller, "Adso von Montier-en-Der und die Frankenkönige," Trierer Zeitschrift für Geschichte und Kunst des Trierer Landes und seiner Nachbargebiete 40/41 (1977/78): 189-99.

106 Text apud Verhelst, Adso Dervensis, 26 (emphasis original). "Hence the apostle Paul says that the Antichrist will not come into the world unless first comes the falling-away, i.e., unless first all kingdoms fall away from the Roman Empire to which they were long subject. The time has not yet come, because, though we see the Roman empire destroyed in great part, nevertheless as long as the kings of the Franks who hold the empire by right shall last, the dignity of the Roman empire will not totally perish, because it will endure in its kings" (translation McGinn, Visions of the End, 86). 
And thus the fourth and final world-empire of the schema became located in Western Europe in name as well as in notion.

The gradual transposition of the translatio imperii from the East to the West culminated in the twelfth century. One reason for urgency was the papal schism of 1159-1178, which had galvanized the West against incursions from the Byzantines. ${ }^{107}$ Another was the Investiture Controversy, which overshadowed politics throughout the last decades of the eleventh century and quickened the development of political identity in the transalpine states, especially in Germany. ${ }^{108}$ One should not overlook, either, the superlative quality of the men who held the throne during this period. Paramount here are Friedrich I "Barbarossa" (1122-119o) and his grandson, the Sicilian Friedrich II (1194-1250), surnamed "Stupor Mundi" ("the Wonder of the World") by his admirers and preambulus Antichristi ("forerunner of the Antichrist") by his enemies. ${ }^{109}$ These were Emperors in the mold of Trajan or Marcus Aurelius.

The internal vigor in the western states translated into a newfound sense of identity that was articulated in emergent ethno-nationalisms. The attitude reveals itself in several works, including the Chronica of Otto of Freising (Otto Frisingensis, ca. 1114-1158), which was composed in the middle of the twelfth century. ${ }^{110}$ In his retrospective account of the significance of Charlemagne's reign, Otto re-directed the translatio imperii after Rome and Byzantium to the Holy Roman Empire via Charlemagne: Igitur Karolus regno romanorum ad francos translato ... ("And so Charles transferred the reign of the Romans to the Franks ..."). ${ }^{111}$ But Otto's grander historiographic purpose is evident in his Prologue:

Regnum romanorum, quod in Daniele propter tocius orbis bello domiti singularem principatum, quam greci monarchiam uocant, ferro comparatur,

107 Robert L. Benson, "Political Renovatio: Two Models from Roman Antiquity," in Renaissance and Renewal in the Twelfth Century, ed. Robert L. Benson and Giles Constable with Carol D. Lanham (Oxford: Clarendon Press, 1982), 339-86 at 370-72; and Goez, Translatio imperii.

108 Scales, Shaping of German Identity, 282.

109 Wolfgang Stürner, "Friedrich II. Antichrist und Friedenskaiser," in Menschen, die Geschichte schrieben, ed. A. Schneider and M. Neumann (Wiesbaden: Marix, 2014), 19-36.

110 Lukas G. Grzybowski, "Fundamentos do poder imperial em meados do século XII: A fortitudo e a translatio imperii na obra de Otto de Freising," Revista de história, Juiz de Fora 22 (2016): 69-91; and Jay Rubenstein, Nebuchadnezzar's Dream: The Crusades, Apocalyptic Prophecy, and the End of History (Oxford: Oxford University Press, 2019), 126-40.

111 Otto Frisingensis, Chronica, siue historia de duabus civitatibus, book 5, §XXXII, lines 8-9= Adolfus Hofmeister, Ottonis episcopi frisingensis. Chronica; siue, Historia de duabus civitatibus, MGH ss rer. Germ. 45 (Hannover; Leipzig: Hahn, 1912), 257 (translation mine). 
ex tot alternationibus, maxime diebus nostris, ex nobilissimo factum est pene nouissimum, ut iuxta poetam uix "magni stet nominis umbra." Ab Urbe quippe ad grecos, a grecis ad francos, a francis ad lonbardos, a lonbardis rursum ad teutonicos francos deriuatum non solum antiquitate senuit, sed etiam ipsa mobilitate sui ueluti leuis glarea hac illaque aquis circumiecta sordes multiplices ac defectus uarios contraxit. Ostenditur igitur in ipso capite mundi mundi miseria, ipsiusque occasus toti corpori minatur interitum. ${ }^{112}$

The critical phrase here is "from the Franks to the Lombards, and so from the Lombards to the Germanic Franks," which is emphasized in the quotation. And so, as J. G. A. Pocock observes, "what he [Otto] designed as an Augustinian History de duabus civitatibus becomes in some measure a history de translatione imperii."113

This point is underscored in the earliest surviving illustrated manuscript copy of the Chronica, which dates from the second half of the thirteenth century. It contains two images that are thematically identical to each other. The first is that of the enthroned Augustus Caesar, the second of the enthroned Emperor Otto I, teutonicorum rex ("King of the Teutons")..14 The inference is patent: what had been initiated with the first Roman Emperor is now continued through his Teutonic heirs.

Otto of Freising's extension of the translatio to the Franks is paralleled in the work of his near-contemporary, Frutolf of Michelsberg (d. 1103). As Frutolf asserted in his own Chronica, "the Roman Empire remained in Constantinople and was held by the Empire of the Greeks; it was only through Charles that it was transferred to the kings or emperors of the Franks." 115

\footnotetext{
112 Hofmeister, Chronica, 7-8 (emphasis mine).

113 J. G. A. Pocock, Barbarism and Religion: Volume 3: The First Decline and Fall (Cambridge: Cambridge University Press, 2003), 98.

114 Jena, Thüringer Universitäts- und Landesbibliothek, Bos. q. 6, fols. $38 \mathrm{v}$ (Augustus) and $78 \mathrm{v}$ (Otto I). For the digitized manuscript, see: https://archive.thulb.uni-jena.de/collections/ receive/HisBest_cbu_ooo19205.

115 Jena, Thüringer Universitäts- und Landesbibliothek, Bos. q. 19 (autograph), fol. 142r. For digitized manuscript, see: https://archive.thulb.uni-jena.de/collections/receive/HisBest_ cbu_ooo2855o. Cf. G. Waitz, ed., Ekkehardi Uraugiensis chronica, MGH ss 6 (Hannover, 1844), 1-276. See further Hans-Werner Goetz, "The Concept of Time in the Historiography of the Eleventh and Twelfth Centuries," in Medieval Concepts of the Past: Ritual, Memory, Historiography, ed. Gerd Althoff, Johannes Fried, and Patrick J. Geary (Cambridge: Cambridge University Press, 2002), 139-66 (translation here Goetz, "The Concept of Time," 154).
} 
The chronicles of Otto of Freising and Frutolf of Michelsberg reflect the profound changes that were underway in the thirteenth century in Western Europe. ${ }^{116}$ The 1204 sack of Constantinople greatly reduced the Byzantine Empire, which thereafter became a supporting actor in its own history. The resultant loss of Byzantine prestige on the world stage prompted other groups, including the Armenians and the Syrians, to begin to refer to the Franks, rather the Byzantines, as the "Romans." ${ }^{117}$

At the same time, the evolution of western vernacular languages during this period, and the composition of literature in those languages, as opposed to Latin works that had been inherited from classical antiquity, underwrote the evolution of regional proto-nationalist identities, to which new literary forms such as the chronicles of Otto and Frutolf added necessary historical depth. ${ }^{118}$ Chronicles and histories not only record group identity, they also create it; rulers and lineages that are excluded from the historical stream are as important as those that are included. ${ }^{119}$ Those who write history write the present.

116 These changes were so profound that, in my view, the common mediaeval apocalyptic tradition can be divided into two distinct parts, early and late. The limitations of this paper do not permit a full exposition of the subject; see the essays in the second part of DiTommaso and McAllister, eds., The Common Mediaeval Apocalyptic Tradition (n. 19, above).

117 Christopher MacEvitt, "True Romans: Remembering the Crusades among Eastern Christians," JMedHist 40 (2014): 260-75. For specific examples, see S. Peter Cowe, "The Reception of the Book of Daniel in Late Ancient and Medieval Armenian Society," in The Armenian Apocalyptic Tradition: A Comparative Perspective: Essays Presented in Honor of Professor Robert W. Thompson on His Eightieth Birthday, ed. Kevork B. Bardakjian and Sergio La Porta, SVTP 25 (Leiden: Brill, 2014), 81-125 at 101-12; Zara Pogossian, "The Last Emperor or the Last Armenian King? Some Considerations on Armenian Apocalyptic Literature from the Cilician Period," in The Armenian Apocalyptic Tradition: A Comparative Perspective: Essays Presented in Honor of Professor Robert W. Thompson on His Eightieth Birthday, ed. Kevork B. Bardakjian and Sergio La Porta, SVTP 25 (Leiden: Brill, 2014), 457-503; and James Hamrick's contribution to the present volume, on the schema in its mediaeval Ethiopic milieu. For Byzantine examples, see above, nn. 30, 38, 49, 61. In the Sassanid East, the rise of Islam prompted the incorporation of "Ishmael" into the schema in Syriac Christian circles (see the section, "The Apocryphal Daniel Apocalyptica and the Syriac Apocalyptic Tradition," above).

118 One example: Serban Marin, "Venice and translatio imperii: The Relevance of the 1171 Event in the Venetian Chronicles' Tradition," Annuario dell'Istituto Romeno di Cultura e Ricerca Umanistica di Venezia 3 (2001): 45-103.

119 On the application of the translatio imperii in diverse states during the later mediaeval centuries, see, most recently Luca D’Ascia, "L'epistola di Papa Pio II a Maometto II, un manifesto in favore della translatio imperii," in Conferenze su Pio II: nel sesto centenario della nascita di Enea Silvio Piccolomini (1405-2005), ed. Enzo Mecacci (Siena: Accademia senese degli intronati, 2006), 13-25; Thomas Wetzstein, "La doctrine de la 'translatio imperii' et l'enseignement des canonistes médiévaux," in Science politique et droit publique 
The final step was to gild these emergent identities with the aura of culture. In the Prologue to his Cligès (ca. 1170), Chrétien de Troyes explains how the seat of knowledge had developed in Greece, was transmitted to Rome, and then passed to France. In this fashion the translatio imperii- the transmission of political power-became linked with the notion of translatio studiithe transmission of cultural power. ${ }^{120}$ In this fusion of political and cultural capital lies the genesis of the conception of the transfer of civilization from empire to empire. This is hard-core cultural identity: basically undefinable, often spurious, inevitably hostile to "enemies" on account of its underlying apocalypticism 121 —yet immensely powerful and influential in a way that creates stakeholders among every level of society in the group.

The picture of the translatio imperii that appears in this section is a sketch, not a full portrait. The story of its application over the first half of the mediaeval millennium is more nuanced. It presents many interesting pathways, and contains more than a few dead-ends. But the basic trajectory, with its roots in the four kingdom schema of Daniel and its trunk consisting of the wood of Rome, is one of progressive embranchment. Its main branch worked its way north-westward, after the passing of the Empire in the West and the emergence of the Carolingian spring, into the Frankish kingdoms. From it developed the idea of "western culture" (and thus "western civilization") that until the past century was the heart of the notion of "Europe."

dans les facultés de droit européenes (XIII $-X V I I I^{e}$ siècle), ed. Jacques Krynen and Michael Stolleis, SER 229 (Frankfurt: Vittorio Klostermann, 2008), 185-221; Elise Bartosik-Vélez, "Translatio imperii: Virgil and Peter Martyr's Columbus," cLS 46 (2009): 559-88; Luis Fernández Gallardo, "La idea de translatio imperii en el Castilla del Bajo medievo," AnEM 46 (2016): 751-86; Marilyn Desmond, "Translatio imperii and the Matter of Troy in Angevin Naples: BL Royal MS 20 D I and Royal MS 6 E IX," Italian Studies 72 (2017): 177-91; and Diane Speed, "Translatio Imperii and Gower's Confessio Amantis," in Booldly Bot Meekly: Essays on the Theory and Practice of Translation in Honour of Roger Ellis, ed. Catherine Batt and René Tixie, MT 14 (Turnhout: Brepols, 2018), 379-93.

120 Literally, the "transfer of learning." Recent studies include A. de Murcia Conesa, "República literaria y translatio imperii," RP 21 (2009): 219-32; Katherine A. McLoone, "Translatio studii et imperii in Medieval Romance" (PhD diss., University of California at Los Angeles, 2012); Xavier Renedo Puig, "Ciutats, regnes i universitats: 'translatio studii et imperii' i història de les ciutats en el 'Dotzè del Crestià'," in El Saber i les llengües vernacles a l'època de Llull i Eiximenis: estudis ICREA sobre vernacularització, ed. Anna Alberni et al. (Montserrat: Publicacions de l'Abadia, 2012), 81-110; and Enrico Fenzi, "Translatio studii e translatio imperii: Appunti per un percorso," Interfaces 1 (2015): 170-208.

121 Lorenzo DiTommaso, "The Apocalyptic Other," in Daniel C. Harlow et al., eds., The Other in Second Temple Judaism: Essays in Honor of John J. Collins (Grand Rapids: Eerdmans, 2011), 221-46. 


\section{Conclusions}

The uses of the four kingdom schema in these three case-studies illustrate the two main functional modalities, or "voices," of apocalyptic speculation of the historical type, "revolutionary" and "imperial."122

The revolutionary (or world-rejecting) voice is most associated with Norman Cohn and his landmark 1957 volume, The Pursuit of the Millennium, ${ }^{123}$ but ultimately relies on a conventional understanding of the settings and purposes of the biblical apocalypses of Daniel and Revelation. In this mode, apocalyptic literature serves as the voice of marginalized and persecuted groups. The eschaton signals the imminent overthrow of the oppressor and the group's salvation from the present state of affairs. ${ }^{124}$ The apocalyptic platform here is radically utopian, and its writings operate as crisis literature.

The imperial (or world-accepting) voice is most associated with the work of Bernard McGinn, ${ }^{125}$ and was proposed partly as a corrective to Cohn's argument. Imperial apocalypticism is an expression of the stakeholder elements of a society. It does not proceed from a setting of obvious social disadvantage or the prospect of an imminent and radical upheaval of the present order. The eschatological horizon of the apocalyptic worldview remains in place (as it must), but its urgency and imminence are downplayed or sidetracked in favor of the status quo. The apocalyptic platform here is geared to authority, for which its writings encourage support.

The two voices are often taken to be conflicting but are in fact complimentary. ${ }^{126}$ The key determinant is whether the group for which the apocalyptic revelation is intended considers itself to be located on the outside

122 The information here and in the following paragraphs encapsulates ideas that are expounded in detail in Lorenzo DiTommaso, "Class Consciousness, Group Affiliation, and Apocalyptic Speculation," in The Struggle over Class: Socioeconomic Analysis of Ancient Christian Texts, ed. G. Anthony Keddie, Michael A. Flexsenhar III, and Steven J. Friesen, WGRW (Atlanta: SBL Press, forthcoming 2021). Both modalities are products of mediaeval scholarship, and thus grew out of the field and are not imposed on it. Breed, "History of Reception," refers to the two voices as "anti-imperial" and "imperial," but the label "antiimperial" is not always appropriate in actual cases.

123 Norman Cohn, The Pursuit of the Millennium (London: Secker \& Warburg, 1957).

124 The means by which the imminent overthrow is understood to come about-violent/ activist vs. quietist/passive-is unimportant to this point. See Lorenzo DiTommaso, "Deliverance and Justice: Soteriology in the Book of Daniel," in This World and the World to Come: Soteriology in Early Judaism, ed. Daniel Gurtner, LSTS 74 (London: T\&T Clark, 2011), 71-86.

125 McGinn, Visions of the End, §15, but in reality passim.

126 Magdalino, "The History of the Future," 29-33. See DiTommaso, "Class Consciousness." 
of society, looking in (or the bottom, looking up), or on the inside, looking out (or the top, looking down). "Inside" and "outside" can refer to economic status, social rank, political class, religious affiliation, and even ethnicity. In practice, though, such metrics are usually bound up together in a group's "identity," which is an expression of its self-perception in its own Sitz im Leben.

The uses of the four kingdom schema in the early mediaeval centuries reflect both modalities. Marginalized groups tended to apply the schema in its outsider/revolutionary mode. Correlating the final kingdom with the presentday oppressor fixed the group's location in history, on the cusp of salvation. This usage is common in the Syriac Christian writings discussed above, including the two Syriac Daniel apocalypses and the Syriac original of the Apocalypse of Pseudo-Methodius. ${ }^{127}$

Stakeholder groups, by contrast, applied the schema in its insider/imperial mode, modulated by the translatio imperii, in order to preserve the present order, which they had fought to establish, not overthrow. Identifying the final kingdom with their own rule normalizes their political positions and provides the basis for legitimation and/or social policy. For the Carolingian hierarchy in particular, the eschatological horizon (and its place in it) framed its "larger ambition to reform society and their preoccupation with laying down Christian norms." 128

There are, of course, other illustrations of the use of the four kingdom schema in the early mediaeval era, not only in Byzantium ${ }^{129}$ and in the West, but also by Jewish and Islamic groups. It should be recalled, too, that most apocalyptic texts of the period did not employ the schema or, like the Apocalypse of Pseudo-Methodius, employed a different historiographic framework. This paper simply offers a snapshot of the subject that focuses on three cases, which in turn illustrate a general pattern of social function.

127 We detect the same dynamic in the mediaeval Jewish writings, prompted by the same cause. One opinion held that the fourth and final kingdom remained Rome. Another argued for a hybrid Byzantine Christian/Arab Muslim kingdom. A third view, promulgated by the scholar and exegete Ibn Ezra (1089-ca. 1167), combined Greece and Rome as the third kingdom and identified Muslim rule as the fourth kingdom. See further, Dennis Halft, "Ismāīil Qazvīnī: A Twelfth-/Eighteenth-Century Jewish Convert to Imāmī Sīism and His Critique of Ibn Ezra's Commentary on the Four Kingdoms (Daniel 2:31-45)," in Senses of Scripture: Treasures of Tradition: The Bible in Arabic among Jews, Christians, and Muslims, ed. Miriam Hjälm, BıвA 5 (Leiden: Brill, 2017), 281-304, esp. 289-9o.

128 Miriam Czock, "Creating Futures through the Lens of Revelation in the Rhetoric of Carolingian Reform, ca. 750 to ca. 9oo," in Apocalypse and Reform from Late Antiquity to the Middle Ages, ed. Matthew Gabriele and James T. Palmer (London: Routledge, 2019), 101-19 at 115 .

129 Donald M. Nicol, “The Byzantine View of Western Europe," GRBS 8 (1967): 315-39. 
The investigation of this paper terminates with the twelfth century, ${ }^{130}$ when the common mediaeval apocalyptic tradition began to disintegrate. The change, which occurred gradually, was the result of several factors. The 1204 sack of Constantinople marginalized the Eastern Empire, as noted. Its effect on the history of Western Europe cannot be underestimated. Yet it would be wrong to conclude that the westward flow of Byzantine apocalyptic material suddenly dried up. In fact the opposite occurred. Greek-speaking nobles and scholars began to stream westward, initially to Venice and Milan, carrying with them the intellectual fruit of centuries of Byzantine thought, including apocalyptic prophecies. ${ }^{131}$

The real locomotive for change was located in the West itself, where from the twelfth and thirteenth centuries onwards, the dissolution of the mediaeval apocalyptic tradition occurred. The catalyst was the emergence of regional cultures that defined themselves by a shared language, literature, and sense of the past, as discussed above. ${ }^{132}$ In grossly simplistic terms, we are talking about the embryonic forms of linguistically distinctive nation-states (or national cultures) of Europe and the formation of regional/national identity. New apocalyptic writings sought to interpret the past in light of a present-day setting that was increasingly relevant to specific ethno-political groups.

None of this altered the overall historical-eschatological tenor of mediaeval apocalyptic speculation. ${ }^{133}$ If anything, there was an increase in the number of prophetic-style writings, ${ }^{134}$ mainly because they were now being composed in vernacular languages as well as Latin. Even so, different kinds of material emerged, not only the chronicles of Otto of Freising and Frutolf of Michelsberg as described, but also agglomerate hagiographies such the Legenda Aurea of 1260, cycles of mystery plays, Peter Comestor's Historia Scholastica (ca. 1250),

130 See Brennan Breed's contribution to the present volume, on the subject of the four kingdom schema in the late mediaeval era.

131 Kenneth M. Setton, "The Byzantine Background to the Italian Renaissance," PAPS 100 (1956): 1-76, at 72-76; and Donald M. Nicol, Byzantium and Venice: A Study in Diplomatic and Cultural Relations (Cambridge: Cambridge University Press, 1988), 418-19. The Greek Oracles of Leo the Wise, for example, was reworked into a sequence of popes both historical and eschatological. Several varieties are known, and the collective title for these is Vaticinia de summis pontificibus, or "pope prophecies," were a frequent vehicle for antipapal discontent in the period before the Protestant Reformation.

132 See the section above, "Translatio imperii and the West in the Early Mediaeval Centuries."

133 That being said, the number of "otherworldly" apocalyptic texts (typically in the form of visionary journeys) also began to increase. The Tractatus de purgatorio sancti Patrici and the Visio Tnugdali both date from the second half of the twelfth century.

134 The corpus of these works is large and has not yet been adequately mapped, nor have its parts been coherently related to the social changes of the era. 
and the Bible Historiale (ca. 1297) and its later variations. Manuscript illumination, too, flourished during this period, as did other graphic and plastic arts, from wall frescos to paintings to stained glass. In all cases, apocalyptic tropes such as the four kingdom schema were deployed to serve new concerns in these media. ${ }^{135}$

The second half of the twelfth century also saw the introduction of a powerful historiographic framework that was promulgated Joachim of Fiore. His three-age schema offered a strikingly original framework by which history and its predestined outcome could be organized, and was influential in the Latin west. ${ }^{136}$

At the end of the tenth century, Adso de Montier-en-Der could compile a biography of the Antichrist, written in Latin. His work would have been intelligible to any Latin theologian and, mutatis mutandis, to any of his counterparts in Orthodox Christendom, Judaism, and Islam. Six centuries later, by the time of the European Wars of Religion, competing regional historiographies, each requiring its own place in the translatio imperii and its special version of history, and now powered by an expansionist drive that would translate into the colonization of the globe, would render the ideal of a truly universal Christian salvation-history virtually impossible.

\section{Bibliography}

Adam of Bremen. Gesta Hammaburgensis ecclesiae pontificum, ex rescensione Lappenbergii. MG H ss rer. Germ. 1.11. Hannover: Hahn, 1876.

Adler, William A. "The Apocalyptic Survey of History Adapted by Christians: Daniel's Prophecy of 70 Weeks." Pages 201-38 in The Jewish Apocalyptic Heritage in Early Christianity. Edited by James C. VanderKam and William A. Adler. CR INT 3.4. Assen: Van Gorcum. Minneapolis: Fortress Press, 1996.

Aerts, W. J. and G. A. A. Kortekaas. Die Apokalypse des Pseudo-Methodius: Die ältesten griechischen und lateinischen Übersetzungen. CsCo 569-570. ss 97-98. Louvain: Peeters, 1998.

Alexander, Paul J. The Oracle of Baalbek: The Tiburtine Sibyl in Greek Dress. Dos 10. Washington, DC: Dumbarton Oaks Center for Byzantine Studies, 1967.

135 Cf. Lorenzetti's L'Allegoria ed effetti del buono e del cattivo governo, in the Palazzo Pubblico in Siena, where Satan (and the notion of metaphysical evil) is correlated with civic government rather than morals or a theological stance.

${ }_{13} 6$ See Marjorie Reeves, The Influence of Prophecy in the Later Middle Ages: A Study in Joachimism, 2nd ed. (Notre Dame: University of Notre Dame Press, 1993), among many other studies. 
Alexander, Paul J. Review of Byzantinische Reichseschatologie: Die Periodisierung der Weltgeschichte in den 4. Grossreichen (Daniel 2 und 7) und dem tausendjährigen Friedensreiche (Apok. 20): Eine motivgeschichtliche Untersuchung, by Gerhard Podskalsky. Speculum 50 (1975): 144-45.

Alexander, Paul J. The Byzantine Apocalyptic Tradition. Berkeley: University of California Press, 1985 .

Bartosik-Vélez, Elise. "Translatio imperii: Virgil and Peter Martyr's Columbus." cLS 46 (2009): 559-88.

Bekkum, W. J. van. "Four Kingdoms Will Rule: Echoes of Apocalypticism and Political Reality in Late Antiquity and Medieval Judaism." Pages 101-118 in Endzeiten: Eschatologie in den monotheistischen Weltreligionen. Edited by Wolfram Brandes and Felicitas Schmieder. Millennium Studies 16. Berlin: Walter de Gruyter, 2008.

Benson, Robert L. "Political Renovatio: Two Models from Roman Antiquity." Pages 33986 in Renaissance and Renewal in the Twelfth Century. Edited by Robert L. Benson and Giles Constable with Carol D. Lanham. Oxford: Clarendon Press, 1982.

Berger, Albrecht. "Das apokalyptische Konstantinopel: Topographisches in apokalyptischen Schriften der mittelbyzantinischen Zeit." Pages 135-55 in Endzeiten: Eschatologie in den monotheistischen Weltreligionen. Edited by F. Schmieder and W. Brandes. Millennium Studies 16. Berlin: Walter de Gruyter, 2008.

Bonura, Christopher J. "The Roman Empire of the Apocalypse: History, Eschatology, and the Four Kingdoms of Daniel in Late Antiquity, the Early Medieval Middle East, and Byzantium." PhD diss., University of California, Berkeley, 2019.

Bousset, Wilhelm. Der Antichrist in der Überlieferung des Judentums, des Neuen Testaments und der alten Kirche. Göttingen: Vandenhoeck and Ruprecht, 1895.

Bracke, Wouter, Jan de Maeyer, and Jan Nelis, eds. Renovatio, inventio, absentia imperii: From the Roman Empire to Contemporary Imperialism. Е в HE 6. Turnhout: Brepols, 2018.

Braverman, Jay. Jerome's Commentary on Daniel: A Study of Comparative Jewish and Christian Interpretations of the Hebrew Bible. СвQмS 7. Washington, DC: Catholic Biblical Association of America, 1978.

Breed, Brennan W. "History of Reception." Pages 85-97 in Daniel: A Commentary by Carol A. Newsom with Brennan W. Breed. otL. Louisville: Westminster John Knox, 2014.

Brezeanu, Stelian. "Translatio imperii' und das lateinische Kaiserreich von Konstantinopel." RevRo 14 (1975): 6o7-17.

Brock, Sebastian P. "The Young Daniel: A Syriac Apocalyptic Text on the End, and the Problem of Its Dating." Pages 75-86 in Apocalypticism and Eschatology in Late Antiquity: Encounters in the Abrahamic Religions, 6th-8th Centuries. Edited by Hagit Amirav, Emmanouela Grypeou, and Guy G. Strousma. LAHR 17. Leuven: Peeters, 2017. 
Brock, Sebastian P. "The Small/Young Daniel Re-Edited." Pages 250-84 in The Embroidered Bible: Studies in Biblical Apocrypha and Pseudepigrapha in Honour of Michael E. Stone. Edited by Lorenzo DiTommaso, Matthias Henze, and William Adler. SvTP 26. Leiden: Brill, 2018.

Buitenwerf, Rieuwerd. "The Tiburtine Sibyl (Greek)." Pages 176-88 in Old Testament Pseudepigrapha: More Noncanonical Scriptures: Volume 1. Edited by Richard Bauckham, James R. Davila, and Alexander Panayotov. Grand Rapids: Eerdmans, 2013.

Capelli, Piero. "Periodizzazioni del tempo: la soluzione apocalittica." RSB 9 (1997): 193-214.

Cartwright, Steven R. and Kevin L. Hughes. Second Thessalonians: Two Early Medieval Apocalyptic Commentaries. TEAms Commentary Series. Kalamazoo: Medieval Institute Publications, 2001.

Chabot, Jean-Baptiste. "L'Apocalypse d'Esdras touchant le royaume des Arabes." RSém 2 (1894): 242-5o and 333-46.

Cohn, Norman. The Pursuit of the Millennium. London: Secker \& Warburg, 1957.

Collins, John J. Apocalypticism in the Dead Sea Scrolls. London: Routledge, 1997.

Collins, John J. The Apocalyptic Imagination: An Introduction to Jewish Apocalyptic Literature. 3rd ed. Grand Rapids: Eerdmans, 2016.

Courtray, Régis. "Der Danielkommentar des Hieronymus." Pages 123-50 in Die Geschichte der Daniel-Auslegung in Judentum, Christentum und Islam. Edited by Katharina Bracht and David S. Du Toit. BZAW 371. Berlin: Walter de Gruyter, 2007.

Courtray, Régis. Prophète des temps derniers. Jérôme commente Daniel. TH 119. Paris: Beauchesne, 2009.

Cowe, S. Peter. "The Reception of the Book of Daniel in Late Ancient and Medieval Armenian Society." Pages 81-125 in The Armenian Apocalyptic Tradition: A Comparative Perspective: Essays Presented in Honor of Professor Robert W. Thompson on His Eightieth Birthday. Edited by Kevork B. Bardakjian and Sergio La Porta. SVTP 25. Leiden: Brill, 2014.

Czock, Miriam. "Creating Futures through the Lens of Revelation in the Rhetoric of Carolingian Reform, ca. 750 to ca. 900." Pages 101-19 in Apocalypse and Reform from Late Antiquity to the Middle Ages. Edited by Matthew Gabriele and James T. Palmer. London: Routledge, 2019.

D’Ascia, Luca. "L'epistola di Papa Pio II a Maometto II, un manifesto in favore della translatio imperii." Pages 13-25 in Conferenze su Pio II: nel sesto centenario della nascita di Enea Silvio Piccolomini (1405-2005). Edited by Enzo Mecacci. Siena: Accademia senese degli intronati, 2006.

Daley, Brian E. The Hope of the Early Church: A Handbook of Patristic Eschatology. Cambridge: Cambridge University Press, 1991. 
Debié, Muriel. "Les apocalypses apocryphes syriaques: des textes pseudépigraphiques de l'Ancien et du Nouveau Testament." Pages 111-46 in Les apocryphes syriaques. Edited by Muriel Débie, Alain Desreumaux, Christelle Jullien, and Florence Jullien. ES 2. Paris: Geuthner, 2005.

Debié, Muriel. "Muslim-Christian Controversy in an Unedited Syriac Text: Revelations and Testimonies about Our Lord's Dispensation." Pages 225-35 in The Encounter of Eastern Christianity with Early Islam. Edited by Emmanouela Grypeou, Mark N. Swanson, and David R. Thomas. Leiden: Brill, 2006.

Delgado, Mariano, and Volker Leppin, eds. Der Antichrist: Historische und systematische Zugänge. Stuttgart: Kohlhammer, 2011.

Desmond, Marilyn. "Translatio imperii and the Matter of Troy in Angevin Naples: BL Royal MS 20 D I and Royal MS 6 E IX." Italian Studies 72 (2017): 177-91.

DiTommaso, Lorenzo. The Book of Daniel and the Apocryphal Daniel Literature. SvTP 25. Leiden: Brill, 2005 .

DiTommaso, Lorenzo. "History and Apocalyptic Eschatology: A Reply to J. Y. Jindo." VT 56 (2006): 413-18.

DiTommaso, Lorenzo. “The Apocalyptic Other." Pages 221-46 in The Other in Second Temple Judaism: Essays in Honor of John J. Collins. Edited by Daniel C. Harlow, Karina Martin Hogan, Matthew Goff, and Joel S. Kaminsky. Grand Rapids: Eerdmans, 2011.

DiTommaso, Lorenzo. "Deliverance and Justice: Soteriology in the Book of Daniel." Pages 71-86 in This World and the World to Come: Soteriology in Early Judaism. Edited by D. Gurtner. LSTS 74. London: T\&T Clark, 2011.

DiTommaso, Lorenzo. "The Apocalypse of Pseudo-Methodius: Notes on a Recent Edition." MEG 17 (2017): 311-21.

DiTommaso, Lorenzo. "The Apocryphal Daniel Apocalypses: Works, Manuscripts, and Overview." ETL 94 (2018): 275-316.

DiTommaso, Lorenzo. "Apocalyptic Historiography." EC 10 (2019): 435-6o.

DiTommaso, Lorenzo. "Apocalypticism in the Contemporary World." Pages 316-42 in The Cambridge Companion to Apocalyptic Literature. Edited by Colin McAllister. Cambridge: Cambridge University Press, 2020.

DiTommaso, Lorenzo. "Il genere 'apocalisse' e l'apocalittico' nella tarda antichità." In Enrico Norelli, ed., Rivista di storia del cristianesimo 17 (2020) no. 1: Apocalisse come genere: un dibattito ancora attuale?

DiTommaso, Lorenzo. "Class Consciousness, Group Affiliation, and Apocalyptic Speculation." In The Struggle over Class: Socioeconomic Analysis of Ancient Christian Texts. Edited by G. Anthony Keddie, Michael A. Flexsenhar III, and Steven J. Friesen. WGRW. Atlanta: SBL Press (forthcoming 2021).

DiTommaso, Lorenzo. “'Revealed Things' in Apocalyptic Literature.” In Re-Imagining Apocalypticism: Apocalypses, Apocalyptic Literature, and the Dead Sea Scrolls. Edited 
by Lorenzo DiTommaso and Matthew J. Goff. EJL. Atlanta: SB L Press (forthcoming 2021).

DiTommaso, Lorenzo. "The Common Medieval Apocalyptic Tradition." In The Mediaeval Apocalyptic Tradition: From the Twilight of the Roman Empire to the Dawn of Early Modern Europe. Edited by Lorenzo DiTommaso and Colin McAllister. Cambridge: Cambridge University Press (forthcoming).

Donzel, Emeri van, and Andrea Schmidt. Gog and Magog in Early Eastern Christian and Islamic Sources. Leiden: Brill, 2012.

Drijvers, Hans J. W. "The Gospel of the Twelve Apostles: A Syriac Apocalypse from the Early Islamic Period." Pages 189-213 in The Byzantine and Early Islamic Near East: I. Problems in the Literary Source Material. Edited by Averil Cameron and Lawrence I. Conrad. S LAE I 1. Princeton: Darwin Press, 1992.

Eddy, Samuel K. The King is Dead: Studies in the Near Eastern Resistance to Hellenism 334-31 BC. Lincoln: University of Nebraska Press, 1961.

Emmerson, Richard K. "Antichrist as Anti-Saint: The Significance of Abbot Adso's Libellus de Antichristo." AmBR 30 (1979): 175-9o.

Emmerson, Richard K. Antichrist in the Middle Ages: A Study of Medieval Apocalypticism, Art, and Literature. Seattle: University of Washington Press, 1981.

Fenzi, Enrico. “Translatio studii e translatio imperii: Appunti per un percorso." Interfaces 1 (2015): 170-208.

Fernández Gallardo, Luis. "La idea de translatio imperii en el Castilla del Bajo medievo." AnEM 46 (2016): 751-86.

Fleckenstein, Josef. “Zum mittelalterlichen Geschichtsbewußtsein.” Pages 53-67 in Archäologie und Geschichtsbewußtsein. Edited by Hermann Müller-Karpe. Munich: C. H. Beck, 1982.

Flusser, David. "The Four Empires in the Fourth Sibyl and the Book of Daniel." IOs 2 (1972): 148-75.

Frenz, T. “Textkritische Untersuchungen zu 'Pseudo-Methodios.' Das Verhältnis der griechischen zur ältesten lateinischen Fassung." ByzZ 8o (1987): 50-58.

Furtado, Rodrigo. “The Chronica Prophetica in MS. Madrid, RAH Aem. 78." Pages 75100 in Forme di accesso al sapere in età tardoantica e altomedievale: raccolta delle relazioni discusse nell'incontro internazionale di Trieste, Biblioteca Statale, 24-25 settembre 2015. Edited by Lucio Cristante and Vanni Veronesi. Polymnia 19. Trieste: Edizioni Università di Trieste, 2016.

Gabriele, Matthew. An Empire of Memory: The Legend of Charlemagne, the Franks, and Jerusalem before the First Crusade. Oxford: Oxford University Press, 2011.

Garstad, Benjamin. Apocalypse of Pseudo-Methodius: An Alexandrine World Chronicle. DOML 14. Cambridge, MA: Harvard University Press, 2012.

Glessmer, Uwe. “Die 'vier Reiche' aus Daniel in der targumischen Literatur." Pages 46898 in vol. 2 of The Book of Daniel: Composition and Reception. Edited by John J. Collins 
and Peter W. Flint with the assistance of Cameron VanEpps. VTSup 83. FIOTL 2. Leiden: Brill, 2001.

Glorie, Franciscus, ed. Commentariorum in Danielem libri III. CCSA 75A. Turnhout: Brepols, 1964 .

Goetz, Hans-Werner. "The Concept of Time in the Historiography of the Eleventh and Twelfth Centuries." Pages 139-66 in Medieval Concepts of the Past: Ritual, Memory, Historiography. Edited Gerd Althoff, Johannes Fried, and Patrick J. Geary. Cambridge: Cambridge University Press, 2002.

Goez, Werner. Translatio imperii: Ein Beitrag zur Geschichte des Geschichtsdenkens und der politischen Theorien im Mittelalter und in der frühen Neuzeit. Tübingen: Mohr, 1958.

Goez, Werner. "Die Danielrezeption in Abendland: Spätantike und Mittelalter." Pages 176-97 in Europa, Tausendjähriges Reich und Neue Welt: ZweiJahrtausende Geschichte und Utopie in der Rezeption des Danielbuches. Edited by Mariano Delgado, Klaus Koch, and Edgar Marsch. Freiburg: Universitätsverlag. Stuttgart: Kohlhammer, 2003.

Goulder, M. D. "The Phasing of the Future." Pages 391-408 in Texts and Contexts: Biblical Texts in Their Textual and Situational Contexts: Essays in Honor of Lars Hartman. Edited by Tord Fornberg and David Hellholm. Oslo: Scandinavian University Press, 1995.

Greisiger, Lutz. Messias-Endkaiser-Antichrist: Politische Apokalyptik unter Juden und Christen des Nahen Ostens am Vorabend der arabischen Eroberung. овс 21. Wiesbaden: Harrassowitz, 2014.

Greisiger, Lutz. "Opening the Gates of the North in 627: War, Anti-Byzantine Sentiment and Apocalyptic Expectancy in the Near East prior to the Arab Invasion." Pages 63-79 in Peoples of the Apocalypse: Eschatological Beliefs and Political Scenarios. Edited by Wolfram Brandes, Felicitas Schmieder, and Rebekka Voß. Millennium Studies 63. Berlin: Walter de Gruyter, 2016.

Grzybowski, Lukas G. "Fundamentos do poder imperial em meados do século XII: A fortitudo e a translatio imperii na obra de Otto de Freising." Revista de história, Juiz de Fora 22 (2016): 69-91.

Guermandi, Maria Pia, and Silvia Urbini, eds. Imperiituro: Renovatio imperii: Ravenna nell'Europa ottoniana. Bologna: IBC, 2014.

Haefele, Hans F., ed. Notker der Stammler, Taten Kaiser Karls des Großen: Notkeri Balbuli Gesta Karoli Magni imperatoris. MG HSRG. Berlin: Weidmann, 1959.

Halft, Dennis. "Ismācil Qazvīnī: A Twelfth-/Eighteenth-Century Jewish Convert to Imāmī Sīism and His Critique of Ibn Ezra's Commentary on the Four Kingdoms (Daniel 2:31-45)." Pages 281-305 in Senses of Scripture: Treasures of Tradition: The Bible in Arabic among Jews, Christians, and Muslims. Edited by Miriam Hjälm. в I BA 5. Leiden: Brill, 2017. 
Herren, Michael W. "The 'Revelationes' of Pseudo-Methodius in the Eighth Century." Pages 409-18 in Felici curiositate: Studies in Latin Literature and Textual Criticism from Antiquity to the Twentieth Century in Honour of Rita Beyers. Edited by Guy Guldentops, Christine Laes, and Gert Partoens. IP M 75. Turnhout: Brepols, 2017.

Hofmeister, Adolfus. Ottonis episcopi frisingensis. Chronica; siue, Historia de duabus civitatibus. MGH Ss rer. Germ. 45. Hannover; Leipzig: Hahn, 1912.

Holdenried, Anke. The Sibyl and Her Scribes: Manuscripts and Interpretation of the Latin Sibylla Tiburtina c. 1050-1500. Aldershot: Ashgate, 2006.

Irshai, Oded. "Dating the Eschaton: Jewish and Christian Apocalyptic Calculations in Late Antiquity." Pages 113-53 in Apocalyptic Time. Edited by Albert I. Baumgarten. NUMENSS 86. Leiden: Brill, 2000.

Kerby-Felton, Kathryn. Reformist Apocalypticism and Piers Plowman. Cambridge: Cambridge University Press, 199 .

Kocken, E. J. J. De Theorie van der vier Wereldrijken en van de Overdracht der Wereldheerschappij tot op Innocentius III. Nijmegen: Berkhout, 1935.

Konrad, R. De ortu et tempore Antichristi: Antichristvorstellung und Geschichtsbild des Abtes Adso von Montier-en-Der. Kallmünz: M. Lassleben, 1964.

Kosmin, Paul J. Time and Its Adversaries in the Seleucid Empire. Cambridge, MA: Harvard University Press, 2019.

Kraft, András. "The Last Roman Emperor Topos in the Byzantine Apocalyptic Tradition.” Byzantion 82 (2012): 213-57.

Kratz, Reinhard G. Translatio imperii: Untersuchungen zu den aramäischen Danielzählungen und ihrem theologiegeschichtlichen Umfeld. WMANT 63. Neukirchen-Vluyn: Neukirchener, 1991.

Lamma, A. "Il problema dei due imperi e dell'Italia meridionale nel giudizio delle fonti letterarie dei secoli IX e X." Pages 154-253 in Atti del $3^{\circ}$ Congresso internazionale di studi sull'alto Medioevo (Benevento-Montevergine-Salerno-Amalfi, 14-18 ottobre 1956). Spoleto: Presso la sede del Centro di studi, 1959.

Landes, Richard. "Lest the Millennium Be Fulfilled: Apocalyptic Expectations and the Pattern of Western Chronography 100-80o CE." Pages 137-211 in The Use and Abuse of Eschatology in the Middle Ages. Edited by Werner Verbeke, Daniel Verhelst, and Andries Welkenhuysen. ML 15. Leuven: Leuven University Press, 1988.

Landes, Richard, Andrew Gow, and David C. Van Meter, eds. The Apocalyptic Year 10oo: Religious Expectation and Social Change, 950-1050. Oxford: Oxford University Press, 2003.

Laureys, Marc, and Daniel Verhelst. "Pseudo-Methodius, Revelationes: Textgeschichte und kritische Edition: Ein Leuven-Groninger Forschungsprojekt." Pages 112-36 in The Use and Abuse of Eschatology in the Middle Ages. Edited by Werner Verbeke, Daniel Verhelst, and Andries Welkenhuysen. ML 15. Leuven: Leuven University Press, 1988. 
Leneghan, Francis. "Translatio Imperii: The Old English Orosius and the Rise of Wessex.” Anglia 133 (2015): 656-705.

van Lent, Jos. "The Proto-Fourteenth Vision of Daniel." Pages 309-13 in Christian-Muslim Relations: A Bibliographical History: Volume 1 (6oo-9oo). Edited by David Thomas, Barbara Roggema, Juan Pedro Monferrer Sala, Johannes Pahlitzsch, Mark Swanson, Herman Teule, and John Tolan. Leiden: Brill, 2009.

van Lent, Jos. "The Fourteenth Vision of Daniel." Pages 697-703 in Christian-Muslim Relations. A Bibliographical History: Volume 3 (1050-1200). Edited by David Thomas, Barbara Roggema, Juan Pedro Monferrer Sala, Johannes Pahlitzsch, Mark Swanson, Herman Teule, and John Tolan. Leiden: Brill, 2011.

Leppin, Volker. "Der Antichrist bei Adso von Montier-en-Der." Pages 125-36 in Der Antichrist: Historische und systematische Zugänge. Edited by Mariano Delgado and Volker Leppin. Stuttgart: Kohlhammer, 2011.

Lolos, Anastasios. Die Apokalypse des Ps.-Methodios. BzKP 83. Meisenheim: Hain, 1976. Lolos, Anastasios. Die dritte und vierte redaktion des Ps.-Methodios. BZKP 94. Meisenheim: Hain, 1978.

MacEvitt, Christopher. "True Romans: Remembering the Crusades among Eastern Christians." JMedHist 40 (2014): 26o-75.

MacLean, Simon. "Reform, Queenship and the End of the World in Tenth-Century France: Adso's 'Letter on the Origin and Time of the Antichrist' Reconsidered." RBPH 86 (2008): 645-75.

Magdalino, Paul. "The History of the Future and its Uses: Prophecy, Policy and Propaganda." Pages 3-34 in The Making of Byzantine History: Studies Dedicated to Donald M. Nicol on his Seventieth Birthday. Edited by Roderick Beaton and Charlotte Roueché. Aldershot: Variorum, 1993.

Marin, Serban. "Venice and translatio imperii: The Relevance of the 1171 Event in the Venetian Chronicles' Tradition." Annuario dell'Istituto Romeno di Cultura e Ricerca Umanistica di Venezia 3 (2001): 45-103.

Mason, Steve. "Josephus, Daniel, and the Flavian House." Pages 161-91 in Josephus and the History of the Greco-Roman Period: Essays in Memory of Morton Smith. Edited by Fausto Parente and Joseph Sievers. SPB 41. Leiden: Brill, 1994.

Martini, Giuseppe. “Traslatione dell'Impero e donazione di Costantino nel pensiero e nella politica d'Innocenzo III." A SRSP 56/57 (1933/34): 219-362.

McGinn, Bernard. Antichrist: Two Thousand Years of the Human Fascination with Evil. San Francisco: HarperCollins, 1993.

McGinn, Bernard. Visions of the End: Apocalyptic Traditions in the Middle Ages. Rev. ed. New York: Columbia University Press, 1998.

McLoone, Katherine A. "Translatio studii et imperii in Medieval Romance." PhD diss., University of California at Los Angeles, 2012. 
Melnyk, Janet L. R. "The Four Kingdoms in Daniel 2 and 7: Chapters in the History of Interpretation." PhD diss., Emory University, 2001.

Mendels, Doron. "The Five Empires: A Note on a Propagandistic Topos." AJP 102 (1981): $330-37$.

Möhring, Hannes. Der Weltkaiser der Endzeit. MF 3. Stuttgart: Thorbecke, 2000.

Morrison, Karl F., with Henry Grunthal. Carolingian Coinage. Numismatic Notes and Monographs 158. New York: American Numismatic Society, 1967.

Murcia Conesa, Antonio de. "República literaria y translatio imperii." RP 21 (2009): 219-32.

Nicol, Donald M. “The Byzantine View of Western Europe” GRBS 8 (1967): 315-39.

Nicol, Donald M. Byzantium and Venice: A Study in Diplomatic and Cultural Relations. Cambridge: Cambridge University Press, 1988.

Nótári, Tamás. "Translatio imperii-Thoughts on Continuity of Empires in European Political Traditions." AJH 52 (2011): 146-56.

Oegema, Gerbern S. "Die Danielrezeption in der alten Kirche." Pages 84-104 in Europa, Tausendjähriges Reich und Neue Welt: Zwei Jahrtausende Geschichte und Utopie in der Rezeption des Danielbuches. Edited by Mariano Delgado, Klaus Koch, and Edgar Marsch. Freiburg: Universitätsverlag. Stuttgart: Kohlhammer, 2003.

Palmer, James T. The Apocalypse in the Early Middle Ages. Cambridge: Cambridge University Press, 2014.

Pertusi, Agostino. Fine di Bisanzio e fine del mondo: Significato e ruolo storico delle profezie sulla caduta di Costantinopoli in oriente e in occidente. Nss 3. Rome: Istituto Storico Italiano per il Medioevo, 1988.

Peursen, Wido Th. van. "Daniel's Four Kingdoms in the Syriac Tradition." Pages 189-207 in Tradition and Innovation in Biblical Interpretation: Studies Presented to Professor Eep Talstra on the Occasion of His Sixty-Fifth Birthday. Edited by Wido Th. van Peursen and Janet W. Dyk. ssN 57. Leiden: Brill, 2011.

Phelan, Owen. The Formation of Christian Europe: The Carolingians, Baptism and the Imperium Christianum. Oxford: Oxford University Press, 2014.

Pocock, J. G. A. Barbarism and Religion: Volume 3: The First Decline and Fall. Cambridge: Cambridge University Press, 2003.

Podskalsky, Gerhard. Byzantinische Reichseschatologie: Die Periodisierung der Weltgeschichte in den 4. Grossreichen (Daniel 2 und 7) und dem tausendjährigen Friedensreiche (Apok. 20): Eine motivgeschichtliche Untersuchung. Münchener Universitäts-Schriften, Reihe der philosophischen Fakultät 9. Munich:W. Fink, 1972. Pogossian, Zara. "The Last Emperor or the Last Armenian King? Some Considerations on Armenian Apocalyptic Literature from the Cilician Period." Pages 457-503 in The Armenian Apocalyptic Tradition: A Comparative Perspective: Essays Presented in Honor of Professor Robert W. Thompson on His Eightieth Birthday. Edited by Kevork B. Bardakjian and Sergio La Porta. SvTP 25. Leiden: Brill, 2014. 
Pohl, Benjamin. "Translatio imperii Constantini ad Normannos: Constantine the Great as a Possible Model for the Depiction of Rollo in Dudo of St. Quentin's Historia Normannorum." Millennium: Yearbook on the Culture and History of the First Millennium 9 (2012): 299-342.

Prinz, O. "Eine frühe abendländische Aktualisierung der lateinischen Übersetzung des Pseudo-Methodius." DAEM 41 (1985): 1-23.

Rattazzi Papka, Claudia. "The Limits of Apocalypse: Eschatology, Epistemology, and Textuality in the Commedia and Piers Plowman." Pages $233^{-56}$ and $35^{-55}$ in Last Things: Death and the Apocalypse in the Middle Ages. Edited by Caroline Walker Bynum and Paul Freedman. Philadelphia: Pennsylvania University Press, 2000.

Rauh, Horst D. Das Bild des Antichrist im Mittelalter: Vom Tyconius zum deutschen Symbolismus. BGPTM. Münster: Aschendorff, 1973.

Reeves, Marjorie. The Influence of Prophecy in the Later Middle Ages: A Study in Joachimism. 2nd ed. Notre Dame: University of Notre Dame Press, 1993.

Reinink, Gerrit J. "Pseudo-Methodius: A Concept of History in Response to the Rise of Islam." Pages 149-88 in The Byzantine and Early Islamic Near East: I. Problems in the Literary Source Material. Edited by Averil Cameron and Lawrence I. Conrad. SLAE I 1. Princeton: Darwin Press, 1992.

Reinink, Gerrit J. Die syrische Apokalypse des Pseudo-Methodius. Csco 540-41. ss 22021. Leuven: Peeters, 1993.

Renedo Puig, Xavier. "Ciutats, regnes i universitats: 'translatio studii et imperii' i història de les ciutats en el 'Dotzè del Crestià'." Pages 81-110 in El Saber i les llengües vernacles a l'època de Llull i Eiximenis: estudis ICREA sobre vernacularització. Edited by Anna Alberni, Lola Badia, Lluís Cifuentes, and Alexander Fidora. Montserrat: Publicacions de l'Abadia, 2012.

Riedl, Matthias, ed. A Companion to Joachim of Fiore. всст 75. Leiden: Brill, 2018.

Romero-Pose, E., ed. Sancti Beati a Liebana Commentarius in Apocalypsin. 2 vols. Rome: Typis Officinae Polygraphicae, 1985 .

Roth, Norman.Jews, Visigoths and Muslims in Medieval Spain: Cooperation and Conflict. MIPTS 10. Leiden: Brill, 1994.

Rubenstein, Jay. Nebuchadnezzar's Dream: The Crusades, Apocalyptic Prophecy, and the End of History. Oxford: Oxford University Press, 2019.

Rusconi, Roberto. "Antichrist and Antichrists." Pages 287-325 in The Encyclopedia of Apocalypticism: Volume 2: Apocalypticism in Western History and Culture. Edited by Bernard McGinn. New York: Continuum, 1998.

Russell, Jeffrey Burton. The Prince of Darkness: Radical Evil and the Power of Good in History. Ithaca: Cornell University Press, 1988.

Sackur, Ernst. Sibyllinische Texte und Forschungen: Pseudomethodius, Adso und die Tiburtinische Sibylle. Halle a.d. Saale: M. Niemeyer, 1898.

Scales, Len. The Shaping of German Identity: Authority and Crisis, 1245-1414. Cambridge: Cambridge University Press, 2012. 
Schiffman, Lawrence H. "Messianism and Apocalypticism in Rabbinic Texts." Pages 1053-72 in The Cambridge History of Judaism: Vol. IV: The Late Roman-Rabbinic Period. Edited by Steven T. Katz. Cambridge: Cambridge University Press, 2006.

Schmale, Franz-Josef. Funktion und Formen mittelalterlicher Geschichtsschreibung: Eine Einführung. Darmstadt: Wissenschaftliche Buchgesellschaft, 1985.

Schneidmüller, B. "Adso von Montier-en-Der und die Frankenkönige." Trierer Zeitschrift für Geschichte und Kunst des Trierer Landes und seiner Nachbargebiete 40/41 (1977/78): 189-99.

Setton, Kenneth M. "The Byzantine Background to the Italian Renaissance." PAPS 100 (1956): 1-76.

Shimohara, Sumi. "Peut-on parler de millénarisme à l'époque carolingienne? L'apport de quelques sources exégétiques." TM 14 (2006): 99-138.

Shoemaker, Stephen J. "The Tiburtine Sibyl: A New Translation and Introduction." Pages 510-25 in New Testament Apocrypha: More Noncanonical Scriptures: Volume 1. Edited by Tony Burke and Brent Landau. Grand Rapids: Eerdmans, 2016.

Shoemaker, Stephen J. The Apocalypse of Empire: Imperial Eschatology in Late Antique and Early Islam. Philadelphia: University of Pennsylvania Press, 2018.

Speed, Diane. "Translatio Imperii and Gower's Confessio Amantis." Pages 379-93 in Booldly Bot Meekly: Essays on the Theory and Practice of Translation in Honour of Roger Ellis. Edited by Catherine Batt and René Tixier. MT 14. Turnhout: Brepols, 2018. Stöllinger-Löser, Christine. "Chuseth, Pseudo-Methodius und Rudolf von Ems: Wer war die Mutter Alexanders des Großen." AssL 155 (2003): 347-54.

Stone, Michael E. Ancient Judaism: New Visions and Views. Grand Rapids: Eerdmans, 2011.

Stouraitis, Ioannis. "Byzantine Romanness: From Geopolitical to Ethnic Conceptions." Pages 123-40 in Transformations of Romanness: Early Medieval Regions and Identities. Edited by Walter Pohl, Clemens Gantner, Cinzia Grifoni, and Marianne Pollheimer-Mohaupt. Millennium Studies 77. Berlin: Walter de Gruyter, 2018.

Stürner, Wolfgang. "Friedrich II. Antichrist und Friedenskaiser." Pages 19-36 in Menschen, die Geschichte schrieben. Edited A. Schneider and M. Neumann. Wiesbaden: Marix, 2014.

Swain, Joseph Ward. "The Theory of the Four Monarchies: Opposition History under the Roman Empire." CP 25 (1940): 1-21.

Thomas, David, Barbara Roggema, Juan Pedro Monferrer Sala, Johannes Pahlitzsch, Mark Swanson, Herman Teule, and John Tolan, eds. Christian-Muslim Relations: A Bibliographical History: Volume 1 (600-900). Leiden: Brill, 2009.

Travassos Valdez, Maria Ana. Historical Interpretations of the "Fifth Empire": The Dynamics of Periodization from Daniel to António Vieira, S. J. SHCT 149. Leiden: Brill, 2010.

Tsirpanlis, Constantine N. "Byzantine Reactions to the Coronation of Charlemagne (78o-813)." Byzantina 6 (1974): 345-6o. 
Ubierna, Pablo. "Recherches sur l'apocalyptique syriaque et byzantine au VII ${ }^{\mathrm{e}}$ siècle: la place de l'Empire romain dans une histoire du salut." вCEMA 2 (2008): 1-28.

Ubierna, Pablo. "Byzantine Greek Apocalypses and the West: A Case Study." Pages 20518 in Apocalypticism and Eschatology in Late Antiquity: Encounters in the Abrahamic Religions, 6th-8th Centuries. Edited by Hagit Amirav, Emmanouela Grypeou, and Guy G. Strousma. LAHR 17. Leuven: Peeters, 2017.

Verhelst, Daniel. Adso Dervensis, De ortu et tempore Antichristi, necnon et tractatus qui ab eo dependunt. сссм 45. Turnhout: Brepols, 1976.

Villagomez, Cynthia. "Christian Salvation through Muslim Domination: Divine Punishment and Syriac Apocalyptic Expectation in the Seventh and Eighth Centuries." ME 4 (1998): 204-18.

Waitz, G., ed. Ekkehardi Uraugiensis chronica. MGH ss 6. Hannover, 1844.

Warner, David A. "Ideals and Action in the reign of Otto III." JMedHist 25 (1998): 1-18.

Werman, Cana. "Epochs and End-Time: The 49o-Year Scheme in Second Temple Literature." DSD 13 (2006): 229-55.

Wetzstein, Thomas. "La doctrine de la 'translatio imperii' et l'enseignement des canonistes médiévaux." Pages 185-221 in Science politique et droit publique dans les facultés de droit européenes (XIII $-X V I I I^{e}$ siècle). Edited by Jacques Krynen and Michael Stolleis. SER 229. Frankfurt: Vittorio Klostermann, 2008.

Witakowski, Witold. "Syriac Apocalyptic Literature." Pages 667-87 in The Armenian Apocalyptic Tradition: A Comparative Perspective: Essays Presented in Honor of Professor Robert W. Thompson on His Eightieth Birthday. Edited by Kevork B. Bardakjian and Sergio La Porta. SVTP 25. Leiden: Brill, 2014.

Zecchini, Giuseppe. "Latin Historiography: Jerome, Orosius and the Western Chronicles." Pages 317-45 in Greek and Roman Historiography in Late Antiquity: Fourth to Sixth Century A.D. Edited by Gabriele Marasco. Leiden: Brill, 2003. 